\title{
Origin and significance of Lovén's Law in echinoderms
}

\author{
Christopher R. C. Paul ${ }^{1}$ (I) and Frederick H. C. Hotchkiss ${ }^{2}$ \\ ${ }^{1}$ School of Earth Sciences, University of Bristol, Bristol, UK < glcrcp@ bris.ac.uk> \\ ${ }^{2}$ Marine and Paleobiological Research Institute, P.O. Box 1016, Vineyard Haven, Massachusetts, USA $02568<$ hotchkiss@ MPRInstitute. \\ org >
}

\begin{abstract}
Lovén's Law described the position of larger basicoronal ambulacral plates in echinoids. The smaller basicoronal plates form first in ontogeny. We restate Lovén's Law to describe the position of first ambulacral plates using Carpenter's ambulacra and left (L) or right (R) as: AR, BL, CR, DL, ER, with EA the pair of ambulacra both identical and adjacent. First ambulacral plates of the Cambrian edrioasteroid, Walcottidiscus, code identically. The transition from a tri-radiate 1-1-1 pattern to the 2-1-2 ambulacral pattern of Walcottidiscus and other pentaradiate Paleozoic echinoderms results in Lovén's Law. This provides an hypothesis for the origin of Lovén's Law and predicts its widespread occurrence among echinoderm classes.

The 'BD different' pattern of primary brachioles in pentaradiate glyptocystitoid Rhombifera results from subterminal branching of the ambulacra. The ontogenetic sequence was triradiate, then lateral ambulacra bifurcated, and finally second brachioles developed. Positions of second brachioles of pentaradiate glyptocystitoids code as AR, BL, CR, DL, ER. Other examples of Lovén's Law occur in Diploporita, Ophiuroidea, Edrioasteroidea, Edrioblastoidea, Holothuroidea, Ophiocistioidea, and Bothriocidaris. Our working hypothesis is that Lovén's Law arose with pentaradiality. An objective test requires a reliable independent landmark across all classes, which does not exist currently. Our hypothesis is only parsimonious if Lovén's Law arose just once in echinoderm evolution and is widespread within the phylum. So far, both conditions appear to be met, but edrioasteroid first ambulacral cover plates commonly exhibit an alternative Lovén-like pattern of AL, BL, CR, DL, ER, with AB the identical adjacent ambulacra.
\end{abstract}

UUID: http://zoobank.org/4c40d338-8bfa-4515-9037-934f3bbab153

\section{Introduction}

Most echinoids have ambulacra consisting of two columns of alternating plates. The first-formed, so-called basicoronal, ambulacral plates differ in size and which is larger alternates left or right with each ambulacrum around the mouth. Lovén (1874) first noticed this pattern, which has become known as Lovén's Law or Lovén's Rule. It has been claimed to be fundamental to all echinoderms and hence reliable in determining ambulacral homologies (e.g., Mooi et al., 2005). Less broadly, Lovén's Law has also been regarded as a character unique to echinoids. For example, the presence of Lovén's Law in Bothriocidaris has been used to argue that this unique Ordovician echinoderm was a true echinoid (e.g., Durham, 1966b, fig. 3, p. 373). In addition, 10 theoretically possible patterns in which the ambulacral motifs alternate (here called 'Lovén-like' patterns) can occur. Thus, theoretical considerations also suggest that other echinoderm classes might demonstrate Lovénlike patterns, but not represent Lovén's Law exactly as found in echinoids. Here we investigate these alternatives. First, we restate Lovén's Law in more general and less ambiguous terms that we hope are applicable across the phylum Echinodermata. Then, we attempt to understand how Lovén's Law might have originated by describing in detail the development of ambulacra in selected Paleozoic echinoderms with biserial ambulacral structure arranged in a 2-1-2 pattern, building on previous investigations of Paleozoic echinoderms and morphogenetic models (e.g., Bather, 1900; Paul and Smith, 1984; Hotchkiss, 1995, 1998a, b, 2000; de Lussanet, 2011; Rozhnov, 2014). We conclude that Lovén's Law arose as an inevitable result of the development of five ambulacra from three by the branching of the lateral ambulacra in a 2-1-2 ambulacral pattern (see Sprinkle, 1973, fig. 16, p. 43) and should be widespread within the phylum. We accept that there is no embryological evidence for the triradiate stage in echinoderm evolution (R. Mooi, personal communication, 2020), yet lower Cambrian helicoplacoids were triradiate and ancestral to the pentaradiate spiral Helicocystis according to Smith and Zamora (2013, fig. 4). In addition, to test our conclusion requires a reliable independent landmark across all classes, which at present does not exist.

\section{Materials}

Repositories and institutional abbreviations.-Illustrated specimens are deposited in the following institutions: Sedgwick Museum, Cambridge, England (SM); University of Tartu, Natural History Museum, Geology, Estonia (TUG); Cincinnati Museum Center, Cincinnati, Ohio, USA (UC); 
United States National Museum, Washington, DC, USA (USNM).

\section{Lovén's Law}

Lovén (1874) first noticed that in irregular echinoids the first basicoronal plates differed in size in the two ambulacral columns of the corona and furthermore that the larger plate occurred alternately on different sides of the ambulacrum. He instituted a system of denoting the ambulacra by Roman numerals in a clockwise direction as seen in oral view, starting with the ambulacrum immediately clockwise of the periproct (Fig. 1). He further identified the two ambulacral columns as a and b, so a shorthand statement of the position of the larger plates in Lovén's Law (as it has become known) is:

\section{Ia, IIa, IIIb, IVa, Vb}

Lovén further designated interambulacra by Arabic numerals clockwise in oral view, starting with the interambulacrum

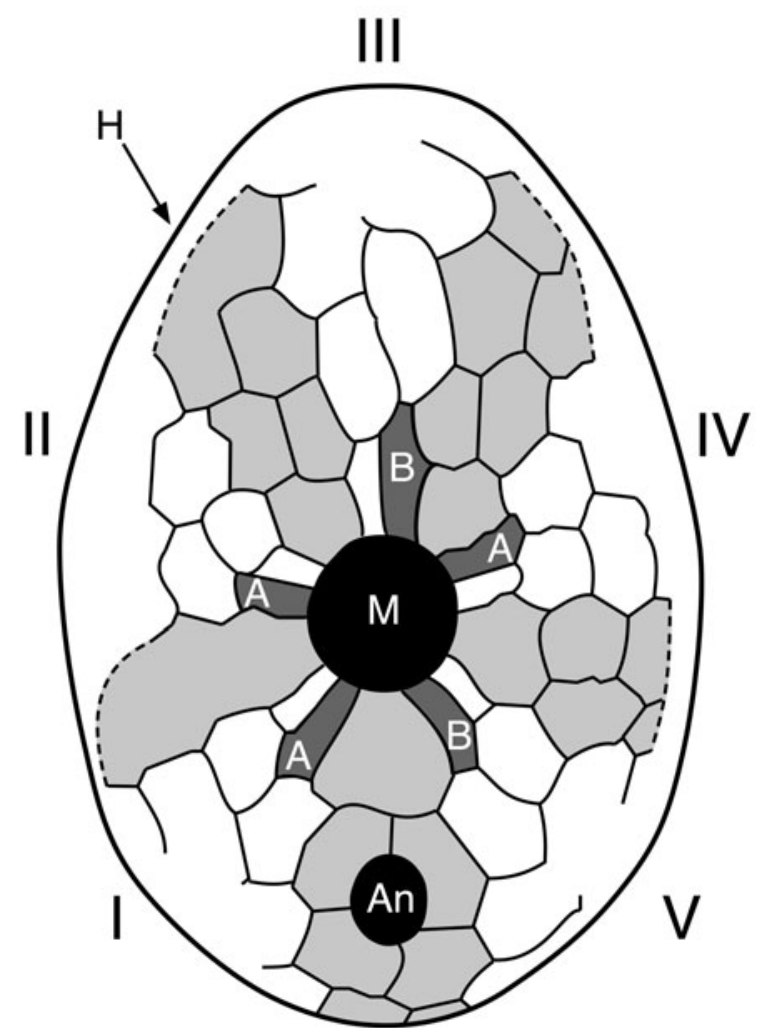

Interambulacra

\section{Larger basicoronal plates}

Figure 1. Lovén's Law as originally proposed by Lovén (1874) and seen in the irregular echinoid Echinocyamus bisexus Kier, 1968. Ambulacra are indicated by Roman numerals. Individual columns within ambulacra indicated by the letters A and B. Lovén's Law states that starting with ambulacrum I and proceeding clockwise in oral view, the larger basicoronal plates occur in columns IA, IIA, IIIB, IVA, VB. An = anus; $\mathrm{H}=$ hydropore (on the opposite surface of the echinoid); $M=$ mouth (redrawn from Hotchkiss, 1978, fig. 1). between his ambulacra I and II. Under this designation, the echinoid hydropore (madreporite) lies in interambulacrum 2 (H, Fig. 1). The only truly interambulacral structure in echinoid coronae is the interradial suture. Four columns of plates are added at the edge of the ocular plates, according to the so-called ocular plate rule (e.g., David et al., 1995): the central pair of pore-bearing, ambulacral plates, and a single column of nonpore-bearing, adambulacral plates, one on either side (Mooi and David, 1997). All four columns are part of the axial skeleton, so in echinoids it is appropriate to restrict the term interambulacral to a position between ambulacra.

In any column of alternating pairs of plates truncated at a smooth surface, such as the edge of the mouth of an echinoid, it is inevitable that one plate will be smaller than the other. Equally, in any system of five ambulacra with a motif that alternates from one ambulacrum to the next, it is inevitable that one motif will occur three times and the other only twice. Furthermore, a unique pair of ambulacra occurs, which are both adjacent and identical.

What justifies the term 'Lovén's Law' is the fact that of the 32 possible arrangements of alternating ambulacral plates (10 Lovén-like and 22 non-Lovénian) only the one first described by Lovén is known to occur in echinoids. Furthermore, it is also present in all regular echinoids that can be scored, not just irregulars. The uniqueness of this pattern can be tested using reliable independent landmarks. In echinoids, the hydropore is always in Lovén's interambulacrum 2, in echinoid larval development the closure of the ring canal is in interambulacrum 4 in all examples studied so far (Saucède et al., 2003, 2007; Tsuchimoto et al., 2011), and in irregular echinoids the periproct is always in interambulacrum 5. Finally, the unique pair of ambulacra are I and II. Thus, use of the term 'Lovén's Law' in echinoids seems justified.

In a collateral study of Paleozoic lysophiurine ophiuroids, 107 rays out of 113 scorable rays, when aligned using the madreporite, conformed with expression of Lovén's Law. On a per-ray basis, the fidelity was 0.947 . Fidelity calculated for five rays is $(0.947)^{5}=0.762$ (Hotchkiss, 1995, p. 424, 432435). At that time, Lovén's Law was not explicit in any 'cystoid' despite purposeful searching (Jackson, 1929, p. 495; Mortensen, 1930, p. 343; Hotchkiss, 1995, p. 418; Smith, 1997).

\section{Modification}

David et al. (1995) showed that 'Lovén's Law' is more than an interesting pattern found in echinoids, but results from the mode of growth of the ambulacra and the sequence of formation of the ambulacral plates. In particular, they showed that the smaller basicoronal plate was always the first plate to develop in each ambulacrum. David et al. (1995, p. 160, fig. 3) determined this by locating the edge-defining transverse sutures in the ambulacral columns. Thus, it seems to us to make sense to identify the first ambulacral plate when trying to recognize 'Lovén's Law' in other classes of echinoderms. By chance, Lovén chose the second plate in each ambulacrum by describing the positions of the larger basicoronal plate in each ambulacrum of echinoids. Furthermore, we believe that consideration of the details of ambulacral growth is the key to understanding ambulacral 
homologies and recognizing Lovén's Law in other classes of echinoderms.

Secondly, Lovén identified his ambulacral columns by the letters a and b. Hotchkiss (1978, p. 538), in the first attempt to find 'Lovén's Law' in another echinoderm class (the ophiuroids), described the offset of ambulacral plates as 'in Advance of' (A) or 'Behind' (B) plates of the opposite column. We think these two meanings may lead to confusion since the first plate is always behind the second, but may occur in ambulacral column a. So, we recommend using the terms left $(\mathrm{L})$ and right $(\mathrm{R})$, as seen in oral view when looking down the ambulacrum in the direction of growth. Clockwise (C) and anticlockwise (A) are possible alternatives, but $\mathrm{A}$ and $\mathrm{C}$ might lead to confusion with the ambulacra using Carpenter's $(1884,1891)$ system of ambulacral notation (see below).

Finally, the identity of the ambulacra in echinoderms is subject to three different notations (Fig. 2). Lovén's (1874) has precedence and no doubt echinoid workers will continue to use it. Carpenter (1884) introduced an alternative system for the crinoids. He also designated ambulacra clockwise in oral view, but used letters of the alphabet (A-E) and started with the ambulacrum opposite the periproct. Carpenter designated interambulacra by means of the adjacent ambulacra. Thus, the interambulacrum containing the periproct, hydropore, and gonopore in most blastozoans is the CD interambulacrum (Fig. 2). Carpenter (1891) extended this system to blastoids and 'cystoids.' Then Jaekel (1899), thinking he was following Lovén's system, used Roman numerals clockwise from the ambulacrum immediately clockwise of the periproct for edrioasteroids (his Thecoidea) and 'cystoids.' Unfortunately, the periproct is not in homologous interambulacra in irregular echinoids versus other Paleozoic echinoderms, as determined from simultaneous expression of Lovén's Law and 2-1-2 symmetry in the edrioasteroids, Astrocystites Whiteaves, 1897, and Walcottidiscus Bassler, 1935 (= Stromatocystites of Hotchkiss, 1995, figs. 3, 4). Carpenter letters are arranged in 2-1-2 symmetry as DE-A-BC, and Lovén's numerals are arranged in 2-1-2 symmetry as V,I - II - III,IV. Jaekel's influence on blastozoan studies is about as profound as Lovén's on echinoid research. Given the confusion that arises from using the same notation to identify different ambulacra using Lovén's and Jaekel's systems, we think a more unambiguous statement of Lovén's Law can be derived using left $(\mathrm{L})$ and right $(\mathrm{R})$, plus Carpenter's ambulacra (Fig. 3). So, identifying the first ambulacral plate or lateral branch of the radial water vessel and starting with Carpenter's ambulacrum A, we get a pattern in echinoids and in other classes of echinoderms of (Fig. 3):

$$
\text { AR, BL, CR, DL, ER }
$$

This gives three Right and two Left and the unique pair of identical adjacent ambulacra is EA (Fig. 3). Herein, we assume that a 'Lovén-like' pattern with cyclic RLRLR corresponds exactly to 'Lovén's Law.' This becomes our working hypothesis, and implies that Carpenter's ambulacra in echinoids are as indicated in Figure 3.

For further context, there are $2^{5}=32$ differing pentaradiate cyclic arrangements of biserial alternating ambulacral plates that could surround the peristome. The 32 are made up from just eight distinct cyclic patterns: RRRRR, RRRRL, RRRLL,
RRLRL, LLLLL, LLLLR, LLLRR, and LLRLR. The patterns RRRRR and LLLLL can occur in only one arrangement, whereas five cyclic permutations apply to the six other patterns; hence $[2+(5 \times 6)=32]$. The five cyclic versions of RRLRL are all Lovén-like, but only one expresses Lovén's law in any instance. In addition, we recognize the five cyclic versions of LLRLR as Lovén-like and of interest. From prior work, we are aware that probability of phenotypes is not uniformly distributed over the 32 slots of this outcome space (Hotchkiss, 1978, 1995). The probability is concentrated in the slot where Lovén's law is expressed, enabling a Bayesian heuristic for the working hypothesis (Jefferys and Berger, 1992).

\section{Testing homologies and additional assumptions}

To test the working hypothesis above requires a reliable independent landmark. The gonopore cannot be used because echinoids typically have five. The periproct is known to migrate even within blastozoan superfamilies, both from just above the basal circlet to the oral surface (in hemicosmitoid rhombiferans) and, more importantly, from the $\mathrm{CD}$ interambulacrum to the $\mathrm{BC}$ interambulacrum (in glyptocystitoid rhombiferans). Furthermore, irregular echinoids only arose in the Early Jurassic (e.g., Saucède et al., 2007). If the migration of the periproct outside the apical disc were a random process, there would be a 1 in 5 chance that irregular echinoids developed an eccentric periproct between exactly the same two ambulacra as early Paleozoic edrioasteroids and blastozoans. Saucède et al. (2003) have shown that posterior migration of the periproct in echinoids occurred eight separate times, but only once did the periproct succeed in moving outside the apical disc, leading to the monophyletic Irregularia. Nevertheless, all attempts involved the same anterior-posterior axis, so it would seem the process was not random as far as echinoids were concerned.

Paul and Smith (1984, fig. 16, p. 471) regarded the hydropore as a reliable landmark to determine ambulacral homologies. Although not explicitly stated, Paul and Smith (1984, p. 472, fig. 17; Fig. 2) illustrated Jaekel's numbering of ambulacra on the left and Lovén's on the right. Furthermore, the hydropore is always in the CD interambulacrum of edrioasteroids and blastozoans, which implies that Carpenter's ambulacrum A is equivalent to Lovén's ambulacrum V. However, using Lovén's Law to determine ambulacral homology implies that Carpenter's ambulacrum A is equivalent to Lovén's ambulacrum II. So, if one accepts the hydropore as a reliable landmark, then Lovén's Law cannot be applied to other classes of echinoderms. Alternatively, if Lovén's Law does determine ambulacral homologies, then the hydropore is an unreliable landmark. The latter seems distinctly possible given that hydropores occur in all five interambulacra in some ophiuroids (Hyman, 1955, p. 613) and some crinoids (Breimer, 1978, p. T15, T46, fig. 30).

Body plan comparisons at lower taxonomic levels can employ homology markers that are not valid between classes. The madreporite in Paleozoic lysophiurine ophiuroids appears to have had consistent placement in relation to Lovén's Law (Hotchkiss, 1995, p. 434). In 12 of 12 five-rayed specimens that score perfectly for Lovén's Law, the madreporite occupies Lovénian interradius III-IV (below shown to be homologous with Carpenter's interradius BC). The probability of observing 

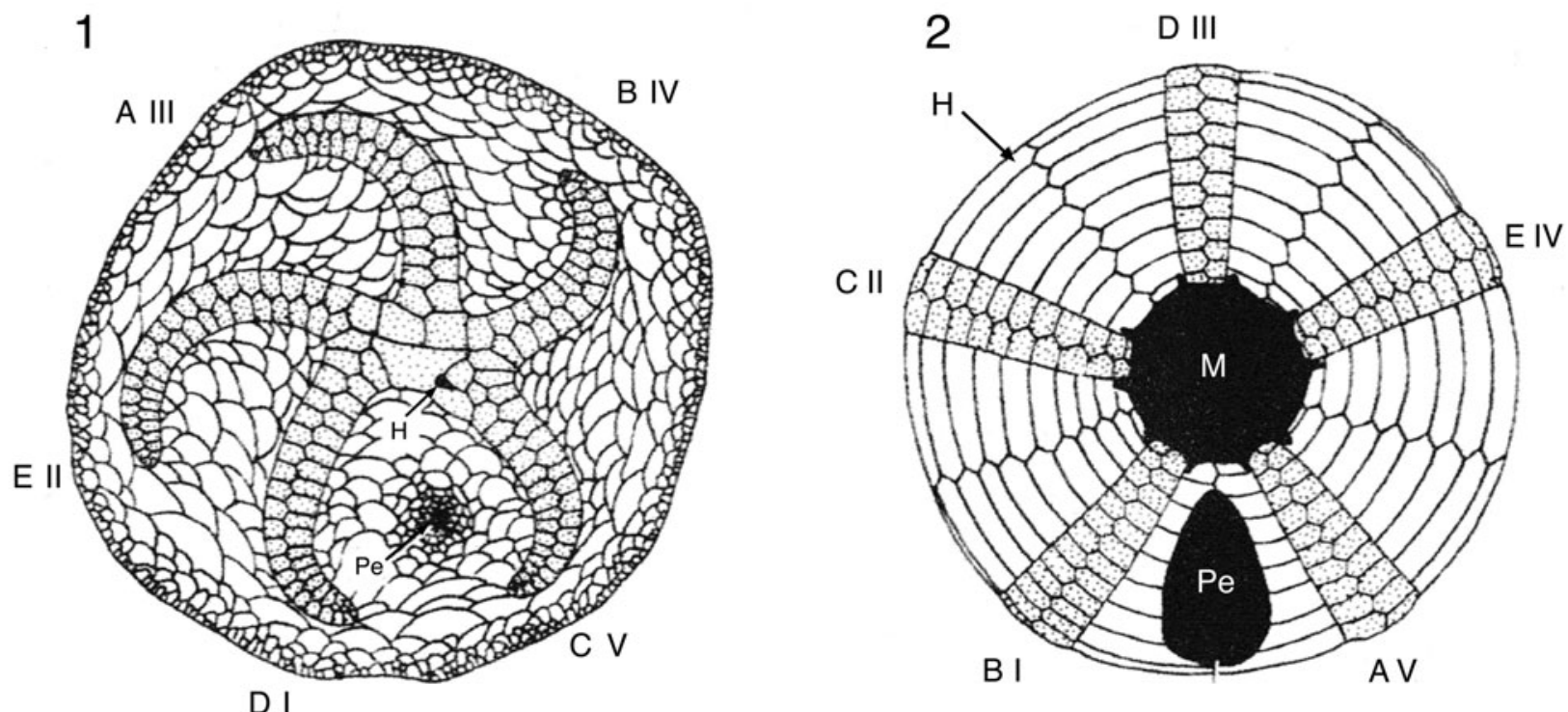

Figure 2. Comparison of systems of ambulacral designation as seen in oral view. (1) Carpenter's rays (A-E) compared with Jaekel's ambulacra (I-V) in edrioasteroids. (2) Carpenter's rays (A-E) compared with Lovén's (I-V) in irregular echinoids. Note that although Jaekel (1899) thought he was copying Lovén (1874) by designating the ambulacrum immediately clockwise to the periproct (Pe) by Roman numeral I, the ambulacra do not coincide because the periproct is in different interambulacra in edrioasteroids and irregular echinoids. Carpenter's $(1884,1891)$ system using letters A-E is unambiguous. $\mathrm{H}=\mathrm{hydropore} ; \mathrm{M}=$ mouth; Pe = periproct (surrounding the anus). Note that the hydropore is on the opposite surface in (2). Modified from Paul and Smith (1984, fig. 17, p. 472).

the madreporite in the same interradius (not specifically the III-IV interradius, but any interradius) by chance in all twelve specimens is $(0.2)^{11}=0.00000002$.

The universal application of Lovén's Law could still be falsified if we could detect a 'Lovén-like' pattern that involved three lefts and two rights, which is commonly the case with edrioasteroid ambulacral cover plates (see below). This raises another important point. In attempting to find a Lovén-like pattern in other classes of echinoderms, we must be sure we are comparing homologous plates. Lovén described his pattern in the first pair of basicoronal plates of sea urchins. The mouth angle plates (MAPP) of asteroids and ophiuroids are directly opposite each other, symmetric, and first in the series of ambulacral plates. There is no possibility that symmetric MAPP could exhibit a Lovén-like pattern, but subsequent pairs of ambulacral plates in some Paleozoic ophiuroids do alternate across the ambulacral midline and are scorable. Although the sense of offset of alternate ambulacral plates does not change along the ambulacrum, we must track back to the MAPP to score the L or R offset. Comparing the first and second plates in one class with the second and third plates in another class will inevitably lead to false conclusions.

Finally, an unspoken assumption in virtually all papers dealing with Lovén's Law is that once laid down the plates maintain their relative positions, although Mooi and David (1997, fig. 1) make this explicit. So, if the first basicoronal plate is on the left (or behind, i.e., adoral to the right plate), during later growth it cannot shift its position and become in advance of the right plate. This means that we can number ambulacral plates or blastozoan brachioles along the ambulacra in the order they occur in adults and be sure the numbers refer to homologous plates or brachioles as well as reflecting the order in which they developed during ontogeny.

\section{Origin of Lovén's Law and the 2-1-2 ambulacral pattern}

Sprinkle (1973) drew attention to the fact that in many blastozoans (and other echinoderms) the ambulacra are arranged in a 2-1-2 pattern (Fig. 4). This pattern can be interpreted in terms of homologies of ambulacra because the unbranched ambulacrum is always central (Carpenter's A), and the branched ambulacra are always lateral. In addition, the gonopore and hydropore are always in the CD interambulacrum and the anus very commonly so as well. This has led some echinoderm workers (e.g., Bather, 1900, fig. 9, p. 11; Fell, 1966, p. 239; Fell and Pawson, 1966, p. 9; Sprinkle, 1973, p. 43; Paul and Smith, 1984, p. 470; Sumrall, 2005, 2008, fig. 11.2, p. 233; Sumrall and Wray, 2007, fig. 1, p. 150) to argue that three primary ambulacra leave the mouth: the $\mathrm{A}, \mathrm{BC}$ combined, and $\mathrm{DE}$ combined. Later in ontogeny, the $\mathrm{B}$ and $\mathrm{C}$ plus the $\mathrm{D}$ and $\mathrm{E}$ ambulacra bifurcate.

Smith's diagram of the oral plating in the Cambrian edrioasteroid Walcottidiscus (= Stromatocystites in Paul and Smith, 1984, fig. 7, p. 454; reversed as Figure 4 herein to show symmetry as seen externally) enables us to suggest how Lovén's Law might have come into being from a triradiate precursor (see Smith and Zamora, 2013, fig. 4). Imagining the 1-1-1 arrangement of the three primary ambulacra radiating from the mouth, we can identify the relevant primary ambulacral plates carried into Walcottidiscus and determine which formed first. In ambulacrum A, the first plate (A1, Fig. 4) is on the right. In the combined $\mathrm{BC}$ ambulacrum, the first plate $(\mathrm{BC} 1)$ is on the left, as it is in the combined DE ambulacrum (DE1). When the combined ambulacra bifurcated, it was inevitable that the new ambulacral plates would develop in the acute angles between the separating ambulacral branches. Thus, irrespective of the relative positions of the first two plates in the combined 


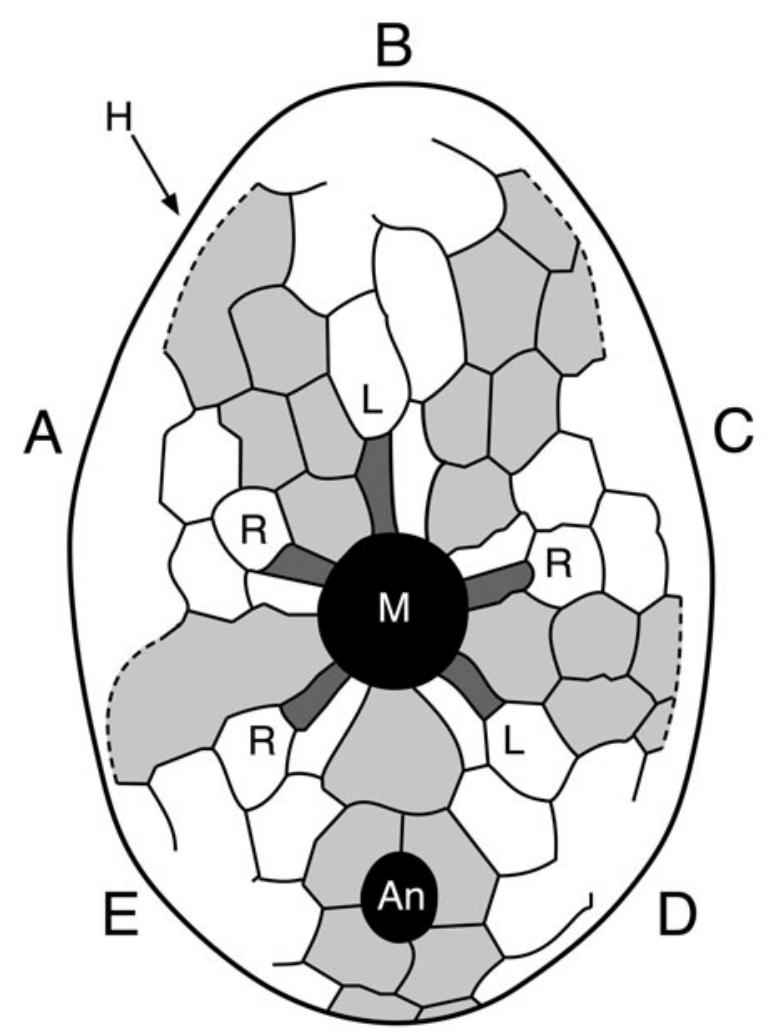

Interambulacra

\section{First basicoronal plates}

Figure 3. Modified version of Lovén's Law using Left (L) and Right (R) terminology and Carpenter's rays (A-E). Note that starting with Carpenter's ray A and identifying the first basicoronal plate in each ambulacrum, Lovén's Law becomes AR, BL, CR, DL, ER and the unique pair of identical adjacent ambulacra are $\mathrm{E}$ and $\mathrm{A}$. $\mathrm{An}=$ anus; $\mathrm{H}=$ hydropore (on the opposite surface of the echinoid); $M=$ mouth (modified from Hotchkiss, 1978, fig. 1).

$\mathrm{BC}$ ambulacrum, ambulacrum $\mathrm{B}$ would have its first plate on the left and ambulacrum $\mathrm{C}$ on the right (compare the positions of $\mathrm{BC} 1$ and $\mathrm{B} 2$, plus $\mathrm{BC} 2$ and $\mathrm{C} 2$ in Fig. 4). The same argument applies to the bifurcation of ambulacra D and E. Thus, Walcottidiscus comes out with a Lovén-like pattern (our Fig. 4 herein), which is, starting at Carpenter's ambulacrum A:

\section{$\mathrm{AR}, \mathrm{BL}, \mathrm{CR}, \mathrm{DL}, \mathrm{ER}$}

The pattern is cyclic RLRLR. There are three rights and two lefts, and the unique identical adjacent ambulacra are $\mathrm{E}$ and A. This gives a plausible hypothesis of how Lovén's Law might have originated as an inevitable result of the combination of biserial ambulacral columns with alternating plates, plus the division of the 1-1-1 pattern of primary ambulacra into five separate ambulacra (D, E separate)-1-(B, C separate) with inevitably reversed motifs. Furthermore, if the bifurcation of the paired ambulacra inevitably results in a pattern of BL, CR, DL, ER, the only possible variation would be the $\mathrm{L} / \mathrm{R}$ scores of ambulacrum A. In Walcottidiscus, the first plate in ambulacrum A is Right; in many edrioasteroids the first primary ambulacral cover plate is Left. Thus, both possible Lovén-like patterns

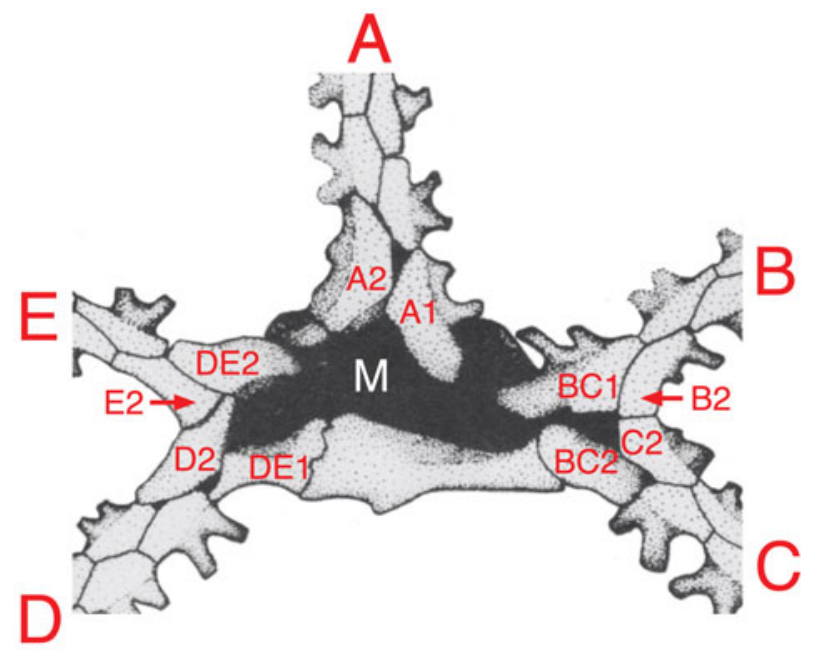

Figure 4. 2-1-2 ambulacral pattern and interpretation of the first 10 ambulacral plates in terms of Lovén's Law in Walcottidiscus. Primary ambulacral plates are assigned the postscript 1 or 2, depending on the inferred order in which they developed, on the assumption that the plate nearest the center of the mouth (M) was developed first. A, BC, and DE are plates of the three primary ambulacra in an assumed triradiate growth stage. Note that when the paired ambulacra bifurcate, there is no alternative position for the new ambulacral plates (B2 and C2 or D2 and E2) other than in the acute angle between the dividing paired ambulacra. This inevitably produces a B left, C right, D left, E right pattern for the first ambulacral plates in ambulacra B-E, irrespective of the position of the original first plate in the paired ambulacra (i.e., BC1 and DE1). The only possible variation is in ambulacrum A, where the first plate might have been on the left or right. In Walcottidiscus, it is on the right, giving the basic Lovén's Law pattern of $\mathrm{AR}, \mathrm{BL}, \mathrm{CR}, \mathrm{DL}, \mathrm{ER}$, with $\mathrm{E}$ and $\mathrm{A}$ the unique pair of identical adjacent ambulacra. (Reversed, cropped, and relabeled from Paul and Smith, 1984, fig. 7A, p. 454; based on USNM 376690).

that could be derived from the transition from a 1-1-1 to a 2-1-2 pattern are known.

\section{Origin of Lovén's Law and the 'BD different pattern' of glyptocystitoid blastozoans}

Paul (1972) recognized that glyptocystitoid rhombiferans (glyptoids for brevity) with five ambulacra always had an unusual arrangement of first brachiole facets. In ambulacra B and D, the first two brachioles were on the left side (as viewed from the mouth in the direction of growth) and thereafter brachiole facets alternated. In ambulacra A, C, and E, only the first facet was on the left and thereafter they alternated regularly. Later (Paul and Donovan, 2011, p. 436; Paul, 2015a, p. 189), this pattern was christened the 'BD different pattern' (Fig. 5). It appears to be plesiomorphic for glyptoids and may have appeared as early as Macrocystella Callaway, 1877 in the Tremadoc (Paul, 1968).

Sumrall (2005, 2008, 2010; Sumrall and Wray, 2007; Sumrall and Waters, 2012) first suggested that Lovén's Law could be recognized in the blastozoan Lepadocystis Carpenter, 1891 (Fig. 6.1, herein). Sumrall $(2005,2008)$ used a very loose definition of Lovén's Law, namely that the two ambulacra that differed from the three in Lovén's original pattern were ambulacra B and D of Carpenter. Since Sumrall noted the unusual ambulacral pattern found in all pentaradiate glyptoids described above, he concluded this was evidence for Lovén's Law in blastozoans. Sumrall (2008) explained the 'BD different 

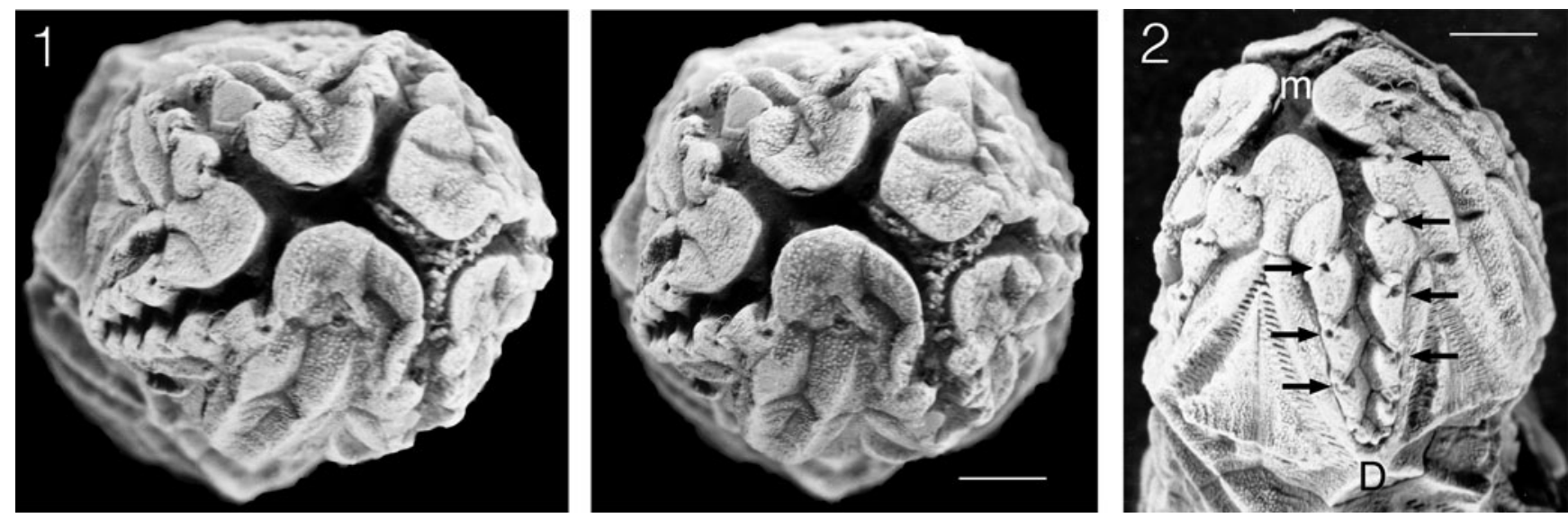

Figure 5. Coronocystis angulatus (Wood, 1909) USNM 113309. (1) Stereophotos of the oral area to show the 'BD different' pattern of primary brachioles. Ambulacra B (mid right) and D (lower left) have the first two brachiole facets to the left and then alternate regularly. The other ambulacra have the first facet left and then alternate regularly. (2) Oblique view of ambulacrum $\mathrm{D}$ to show first two facets on left (top right of photograph). $\mathrm{D}=$ ambulacrum $\mathrm{D} ; \mathrm{m}=$ position of mouth; arrows indicate first seven brachiole facets in ambulacrum D. Note that because the ambulacrum grew down the photograph, anatomical left of the ambulacrum is on the right in (2). Scale bars $=2 \mathrm{~mm}$.

pattern' as arising because the first left facet in the B and D ambulacra represented the first facet of the combined $B+C$ and $\mathrm{D}+\mathrm{E}$ ambulacra, whereas the second left facet represented the first facet of the separate B and D ambulacra. Paul (2015b, p. 626-627) criticized this interpretation on two grounds. First, that the two different ambulacra under Lovén's Law were the A and D ambulacra of Carpenter. This criticism arose from the assumption that the hydropore was a reliable landmark for interpreting ambulacral homologies (see Paul and Smith, 1984, fig. 16, p. 471), and is abandoned here. Secondly, the topology of the branches is wrong. Under the assumption that the radial water vessels branched terminally, the first brachiole in ambulacra B and D should branch before the bifurcation of the B and C, or D and E ambulacra. Indeed, Sumrall (2008, fig. 11.23 ) shows this order of branching, but by the next ontogenetic stage (fig. 11.2 4) the branches to the first brachioles and the division of the ambulacra are at the same place. In practice, the ambulacra divide before (i.e., closer to the mouth) both lateral branches to left brachiole facets in ambulacra B and D. This appeared to be an insuperable difficulty, both with Sumrall's primary brachioles explanation and Paul's first idea that the entire ambulacrum $\mathrm{C}$ was homologous with the 'missing' brachiole $\mathrm{B}^{2}$ and ambulacrum $\mathrm{E}$ homologous with the missing brachiole $\mathrm{D}^{2}$ (see Fig. 6.1).
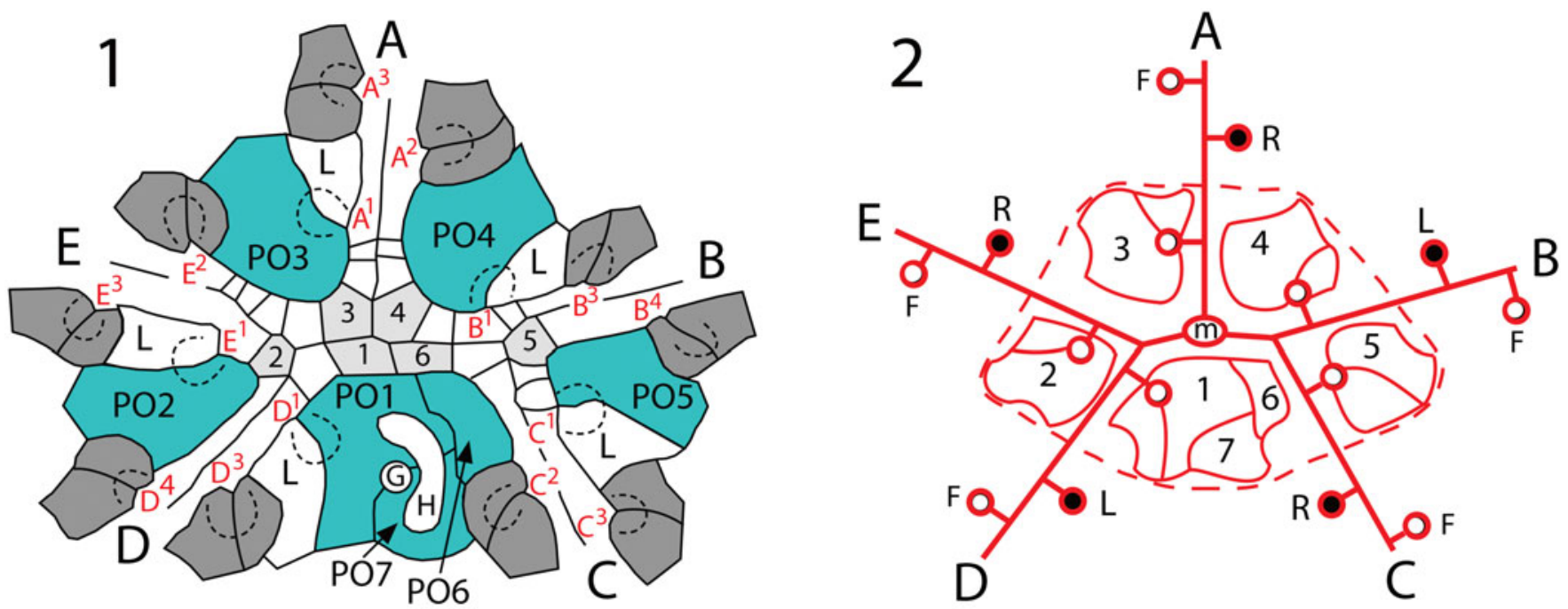

Periorals

Flooring plates

Primary oral cover plates

Figure 6. (1) The 'BD different pattern' of primary brachioles in Lepadocystis moorei (Meek) (UC 57349). A-E $=$ Carpenter ambulacra; $\mathrm{A}^{1}, \mathrm{~A}^{2}$, etc. $=$ primary brachioles of ambulacrum A; $\mathrm{G}=$ gonopore; $\mathrm{H}=$ hydropore; $\mathrm{L}=$ "first left ambulacral floor plates" of Sumrall and Waters (2012); PO1-PO7 = perioral plates; 1 6 = primary ambulacral cover plates. Note that in ambulacra B and D, the first two brachioles, $\mathrm{B}^{1}, \mathrm{~B}^{3}$ and $\mathrm{D}^{1}, \mathrm{D}^{3}$, arise on the left (modified from Paul, 2017, fig. 3, p. 585). (2) Cartoon of Lovén's law as developed in the second brachioles (black circles) of L. moorei, which show the pattern AR, BL, CR, DL, ER, where A-E are Carpenter's ambulacra and $\mathrm{L}=$ left, $\mathrm{R}=$ right, denoting the side of the main ambulacral groove on which the second brachiole lies. $\mathrm{F}=\mathrm{facet} ; \mathrm{m}$ mouth; 1-7 perioral plates 1-7. Dashed line separates the orals and first brachioles of the summit from the second brachioles located below the summit. The first brachioles all diverge to the left, whereas the second brachioles diverge in keeping with Lovén's Law. 
In fact, blastozoan ambulacra branch subterminally, leading to erect brachioles (Fig. 7). It is inevitable that the next lateral branch of the radial water vessel (RWV) to a new brachiole must separate from the main RWV proximal to (i.e., adoral to) the last brachiole facet (arrow, Fig. 7). This is very similar to what happens in echinoids, for example, where the tip of the radial water vessel emerges from the ocular pore. Lateral branches to new tube-feet occur adoral to the ocular plate (i.e., not strictly terminal, but subterminal; Mooi et al., 2005, fig. 2, p. 545). The principal difference is that each terminal blastozoan brachiole acted just once in a manner similar to the permanent behavior of the ocular plate of echinoids.

Sumrall and Sprinkle (1999) described the early ontogeny of Lepadocystis moorei (Meek, 1871). The smallest example they found had only three ambulacra, which they interpreted as the A, BC combined, and DE combined. In a tri-radiate Lepadocystis, the first growth stage of the ambulacra would be just three primary brachioles $\left(\mathrm{A}^{1}, \mathrm{BC}^{1}\right.$, and $\mathrm{DE}^{1}$, Fig. 8.1). Applying the idea that branching of the ambulacra was subterminal, if the next stage was the separation of the $\mathrm{B}$ from the $\mathrm{C}$ ambulacrum and the $\mathrm{D}$ from the $\mathrm{E}$ ambulacrum, then the points of separation are shown by the arrows in Figure 8.1. Figure 8.2 then shows the stage with five ambulacra, each with a single brachiole facet, and the black arrows indicate the branching points for the next stage when each ambulacrum had two brachiole facets (Fig. 8.3). Note
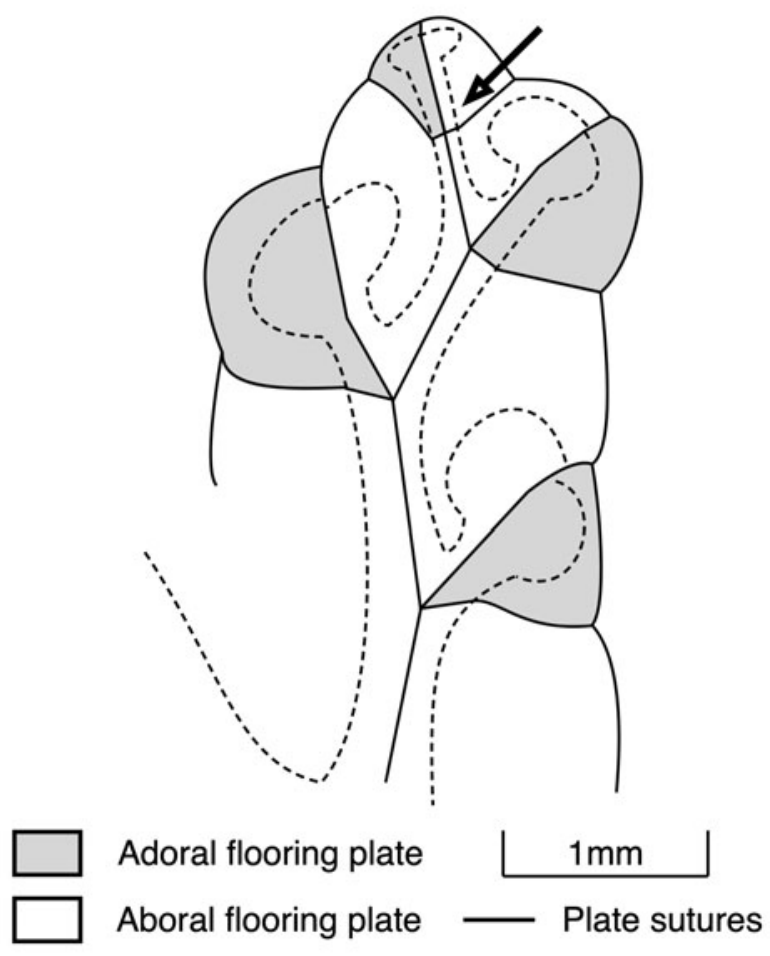

\section{---. Limit of food groove and ambulacral facets}

Figure 7. Camera lucida drawing of terminal ambulacrum of right branch of ambulacrum D in the holotype of Callocystites fresti Paul (SM A85652) to show point of subterminal branching (arrow). Because the last two flooring plates bear a brachiole facet, we assume a brachiole was originally present. The termination of the radial water vessel would be at the tip of that brachiole. Thus, branching in this and all other callocystitids was subterminal. that this has resulted in the observed pattern where the main ambulacra B and C separate before (i.e., adoral to) both the left facets in the B ambulacrum. The same pattern occurs with the D and E ambulacra. Thus, Sumrall $(2005,2008)$ was correct in his interpretation of a three-ambulacrum stage with the first primary brachioles representing $\mathrm{A}^{1}, \mathrm{BC}^{1}$, and $\mathrm{DE}^{1}$. Furthermore, it becomes clear that the brachioles labeled $\mathrm{C}^{1}$ and $\mathrm{E}^{1}$ (Fig. 8.2, 8.3) are homologous with the 'missing' brachioles $\mathrm{B}^{2}$ and $\mathrm{D}^{2}$. Thus, the entire ambulacra $\mathrm{C}$ and $\mathrm{E}$ are indeed homologous with the brachioles $\mathrm{B}^{2}$ and $\mathrm{D}^{2}$. The fact that ambulacral branching in blastozoans must have been subterminal actually predicts the pattern we observe in the 'BD different pattern' of pentaradiate glyptoids. This interpretation assumes three stages between the triradiate first stage and the appearance of the 'BD different pattern.' An alternative possibility, kindly pointed out by Elise Nardin (personal communication to CRCP, 2019) is that when the paired ambulacra were bifurcating to form the first brachiole in ambulacra $\mathrm{C}$ and $\mathrm{E}$, ambulacrum $\mathrm{A}$ also added a second brachiole on the right. We think this is less likely because branching of the paired ambulacra was primarily to achieve a total of five ambulacra. Reaching a stage with three facets in ambulacrum A by the time ambulacra B and D had reached facet 3 does not affect this argument about how the 'BD different pattern' arose.

Terminal ambulacral branching occurs in crinoids, where every lateral branch, whether of the main arm trunk or just to form a pinnule, involves an axillary plate. Indeed, we think that this difference in the mode of growth of the ambulacra in blastozoans and crinoids is possibly the most fundament difference between the two major taxa and considerably more important than the fact that blastozoan ambulacral structures are typically biserial, whereas crinoids have uniserial structures. Exceptions to both generalizations occur.

As far as Lovén's Law is concerned, we explicitly recognize Lovén's Law in the second brachioles of Lepadocystis moorei (Meek, 1871), and explicitly the pattern LLLLL in the first brachioles. The second brachiole facets (Figs. 6.2, 8.3) show a perfect pattern of AR, BL, CR, DL, ER (i.e., three rights and two lefts), with $E$ and $A$ the unique pair of identical adjacent ambulacra as predicted above in considering the 2-1-2 ambulacral pattern and shown to be an inevitable consequence of the way the $\mathrm{BC}$ paired and DE paired ambulacra bifurcate.

A final point concerns the difficulty that this Lovén's Law pattern occurs in the first pairs of plates of the ambulacra in Walcottidiscus, but in the second set of brachioles in Lepadocystis and other pentaradiate glyptoids. Equally, Lovén's Law was first recognized in the first pair of basicoronal plates of echinoids, but also occurs in the second pair of ambulacral plates in ophiuroids; the first pair being the mouth angle plates, which are opposite and symmetric. So, are we comparing like with like in recognizing these Lovén-like patterns?

We would suggest that the answer is 'yes', because wherever along an ambulacrum Lovén's Law first manifests itself, the pattern will continue thereafter. It is simply necessary to trace the pattern back towards the mouth to see where it first appeared in order to make sure we are comparing like with like. So, if mouth angle plates do not show Lovén's Law, but the second pair of ambulacral plates does, we are comparing equivalent plates in all ambulacra. There is a potentially more 

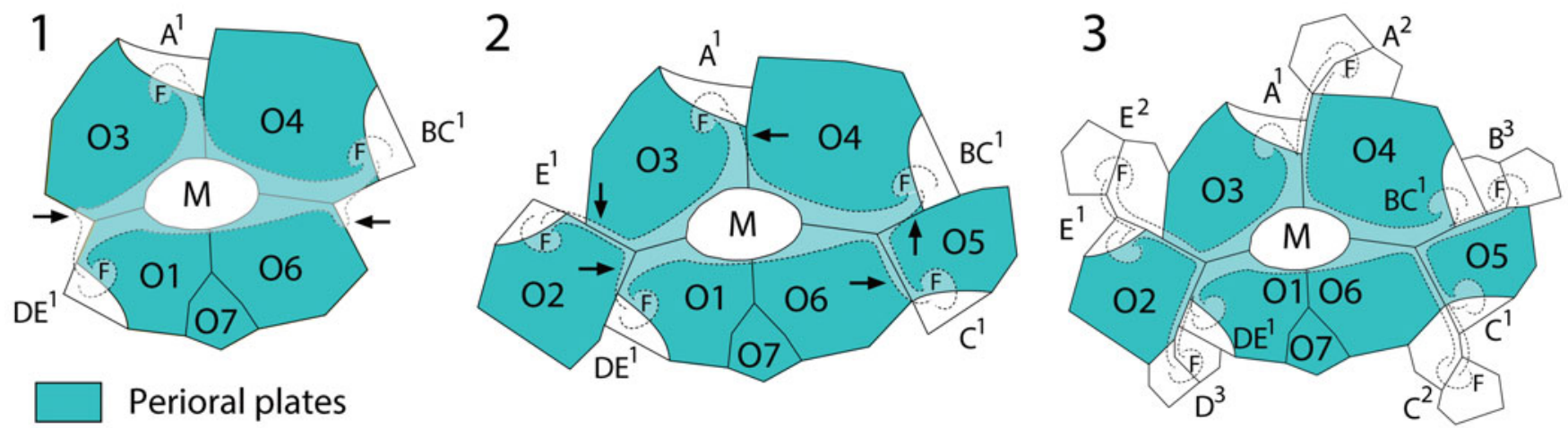

Figure 8. Development of the 'BD different pattern' of primary brachioles in Lepadocystis moorei (Meek). (1) Three-ambulacra stage with a single brachiole (A ${ }^{1}$, $\mathrm{BC}^{1}$, and $\mathrm{DE}^{1}$ ) in each ambulacrum. Arrows point to the positions where the branching to form separate ambulacra $\mathrm{C}$ and $\mathrm{E}$ must have taken place. (2) Five-ambulacra stage with a single brachiole in each ambulacrum. Arrows indicate the branching points necessary to produce a second brachiole in each ambulacrum. (3) Stage with two brachioles in each ambulacrum. Note that this has produced the 'BD different pattern' with the first two facets on the left in ambulacra B and D. Note also, the pattern of the second brachioles in each ambulacrum, which is A right, B left, C right, D left, E right, with A and E the unique pair of identical adjacent ambulacra (i.e., Lovén's Law). A-E = Carpenter's ambulacra; $F=$ brachiole facet; $M=$ mouth; O1-O7 = oral (perioral) plates. Solid lines = plate sutures, dashed lines = outline of peristome and facets.

serious difficulty with glyptoid ambulacra. The ambulacra of Walcottidiscus are biserial, so we are comparing the relative positions of pairs of plates. In glyptoids, the pattern is detected in the second branch of each ambulacrum leading to a brachiole.

Nevertheless, the first brachiole facet is supported by two plates, an oral and an L plate (Fig. 6.1). In ambulacrum A, for example, the plates are PO3 and an L plate. These two plates are on either side of the ambulacrum, and thus constitute the first pair of ambulacral plates. The same is true in all five ambulacra. So, we conclude that the second facets in Lepadocystis and other pentaradiate glyptoids involve the second pair of ambulacral flooring plates and are, therefore, homologous with the plates displaying Lovén's Law in Walcottidiscus and ophiuroids. Thus, we think the basic Lovénian pattern was established in the first pairs of ambulacral plates in Walcottidiscus. Subsequently, in lineages leading to ophiuroids, the first pair of ambulacral plates became modified as equal and opposite mouth angle plates before the first offset plates, which reflect Lovén's Law. In echinoids, the equivalents of the first pair of plates in Walcottidiscus appear to have been lost. In glyptoids, the first pair of plates supporting the first brachiole became modified to obscure the basic Lovénian pattern.

To summarize. The way in which five biserial alternating ambulacra arose from the primary 1-1-1 pattern inevitably results in a Lovénian pattern in the first pairs of ambulacral plates, that is AR, BL, CR, DL. ER, with EA being the unique pair of identical adjacent ambulacra. This pattern can also be derived from the 'BD different pattern' of primary brachiole facets in glyptocystitoid rhombiferans. Thus, a Lovénian pattern can be derived from the mode of development of the ambulacra of pentaradiate echinoderms with a 2-1-2 ambulacral pattern derived from a primary 1-1-1 pattern. This is present in the Cambrian Walcottidiscus and in glyptoids from the Tremadoc to at least the Wenlock. It now remains to see how this relates to Lovén's original observation in post-Paleozoic echinoids. Parsimony suggests that if we have two equally consistent patterns in Paleozoic echinoderms with a 2-1-2 ambulacral pattern and in post-Paleozoic echinoids, it is simpler to assume that they are the same. This assumption can potentially be falsified by the discovery of an alternative Lovén-like pattern, either with a different pair of identical adjacent ambulacra, or with three Left and two Right. The former requires a reliable independent landmark, which the closure of the ring canal might provide for living echinoderm classes. The latter is independent of any landmark.

\section{Additional Paleozoic echinoderms that illustrate Lovén's Law}

Edrioasteroidea.-Edrioasteroids are Paleozoic eleutherozoan echinoderms typically with pentaradiate ambulacra in a 2-1-2 pattern. Bell (1976) subdivided them into two major groups, the Isorophida, which have uniserial ambulacral flooring plates, and the Edrioasterida, which have biserial alternating ambulacral flooring plates. Bell (1976, fig. 2, p. 25) showed that edrioasterid flooring plates are exposed on either side of the ambulacra and align perfectly with the ambulacral cover plates. Edrioasterids also have ambulacral pits, usually interpreted as positions of tube feet, which bear a $1: 1$ relationship to the flooring and cover plates. In Edriophus levis (Bather, 1914), two lines of evidence (flooring plates and cover plates) produce a Lovén like pattern of $\mathrm{AR}, \mathrm{BL}, \mathrm{CR}$, DL, ER; three R, two L, and EA the unique identical adjacent radii. This is identical to the pattern of first basicoronal plates seen in echinoids.

Isorophid edrioasteroids have biserial ambulacral cover plates, accompanied by pores for presumed tube feet in the suborder Lebetodiscina. Cover plates may be added in up to seven generations, making identification of first ambulacral cover plates difficult. Nevertheless, Lovén-like patterns can be coded in nearly 30 species on cover plates, pores, or both (Table 1). In isorophids, virtually without exception, the inevitable BL, CR, DL, ER pattern of mirror image motifs is present. The hydropore sometimes makes the coding of ambulacrum $\mathrm{C}$ particularly difficult. Both possibilities for ambulacrum A occur and AL more frequently than AR (26L, 14R, 5 uncertain; Table 1). In three species, Hemicystites parasiticus Hall, 1852, Krama devonicum (Bassler, 1936), and Hadrochthus commensalis Bell, 1976, different examples have ambulacrum A code 
Table 1. Occurrence of Lovén-like ambulacral patterns in Edrioasteroidea described by Bell, 1976. Under evidence, Floor $=$ flooring plates and Cover $=$ cover plates. 'None' listed under pores for Isorophus austini (Foerste) indicates that no edrioasteroids listed below this level possess ambulacral pores.

\begin{tabular}{|c|c|c|c|c|c|c|c|c|c|c|}
\hline \multirow[b]{2}{*}{ Taxon } & \multicolumn{5}{|c|}{ Ambulacrum } & \multicolumn{5}{|c|}{ Evidence } \\
\hline & A & B & $\mathrm{C}$ & $\mathrm{D}$ & E & Floor & Pores & Cover & Figure & Page \\
\hline \multirow[t]{2}{*}{ Carneyella pilea (Hall, 1866) } & $\mathrm{L}$ & $\mathrm{L}$ & $\mathrm{R}$ & $\mathrm{L}$ & $\mathrm{R}$ & & & \multirow[t]{2}{*}{+} & $1 \mathrm{a}$ & 15 \\
\hline & $\mathrm{L}$ & $\mathrm{L}$ & $?$ & $\mathrm{~L}$ & $\mathrm{R}$ & & + & & $1 \mathrm{a}$ & 15 \\
\hline Foerstediscus splendens Bassler, 1936 & ? & $\mathrm{L}$ & $\mathrm{R}$ & $\mathrm{L}$ & $\mathrm{R}$ & & + & + & $1 d$ & 15 \\
\hline Isorophus cincinnatiensis (Roemer, 1851) & $\mathrm{R}$ & $\mathrm{L}$ & $\mathrm{R}$ & $\mathrm{L}$ & $\mathrm{R}$ & & & + & $1 \mathrm{e}$ & 16 \\
\hline Edriophus levis (Bather, 1914) & $\mathrm{R}$ & $\mathrm{L}$ & $\mathrm{R}$ & $\mathrm{L}$ & $\mathrm{R}$ & + & & + & $2 \mathrm{a}$ & 25 \\
\hline Foerstediscus grandis Bassler, 1935 & $\mathrm{R}$ & $\mathrm{L}$ & $\mathrm{R}$ & $\mathrm{L}$ & $\mathrm{R}$ & & \multirow[t]{3}{*}{+} & & $5 \mathrm{a}$ & 69 \\
\hline Belochthus orthokolus Bell, 1976 & ? & $\mathrm{L}$ & $\mathrm{R}$ & $\mathrm{L}$ & $\mathrm{R}$ & & & + & $8 \mathrm{e}$ & 78 \\
\hline \multirow[t]{3}{*}{ Cystaster granulatus Hall, 1871} & $\mathrm{~L}$ & ? & $\mathrm{R}$ & $\mathrm{L}$ & $\mathrm{R}$ & & & + & $10 \mathrm{a}$ & 96 \\
\hline & $\mathrm{L}$ & $\mathrm{L}$ & $\mathrm{R}$ & $\mathrm{L}$ & $\mathrm{R}$ & & \multirow[t]{6}{*}{+} & + & $11 \mathrm{a}$ & 101 \\
\hline & $\mathrm{L}$ & $\mathrm{L}$ & $\mathrm{R}$ & $\mathrm{L}$ & $\mathrm{R}$ & & & + & $12 \mathrm{a}$ & 103 \\
\hline Carneyella pilea (Hall, 1866) & $\mathrm{L}$ & $\mathrm{L}$ & $\mathrm{R}$ & $\mathrm{L}$ & $\mathrm{R}$ & & & + & $14 \mathrm{a}$ & 119 \\
\hline \multirow[t]{3}{*}{ Cryptogoleus chapmani (Raymond, 1915) } & $\mathrm{L}$ & $\mathrm{L}$ & $\mathrm{R}$ & $\mathrm{L}$ & $\mathrm{R}$ & & & + & $17 \mathrm{~b}$ & 133 \\
\hline & $\mathrm{L}$ & $\mathrm{L}$ & $\mathrm{R}$ & $\mathrm{L}$ & $\mathrm{R}$ & & & \multirow[t]{2}{*}{+} & $18 \mathrm{c}-\mathrm{e}$ & 135 \\
\hline & $\mathrm{L}$ & $\mathrm{L}$ & $?$ & $\mathrm{~L}$ & $\mathrm{R}$ & & & & $18 \mathrm{c}-\mathrm{e}$ & 135 \\
\hline \multirow[t]{4}{*}{ Isorophusella incondita (Raymond, 1915) } & $\mathrm{L}$ & $\mathrm{L}$ & $\mathrm{R}$ & $\mathrm{L}$ & $\mathrm{R}$ & & \multirow{15}{*}{ None } & + & 28 & 177 \\
\hline & $\mathrm{L}$ & $\mathrm{L}$ & $\mathrm{R}$ & $\mathrm{L}$ & $\mathrm{R}$ & & & + & $29 \mathrm{a}, \mathrm{d}$ & 179 \\
\hline & $\mathrm{L}$ & $\mathrm{L}$ & $\mathrm{R}$ & $\mathrm{L}$ & $\mathrm{R}$ & & & + & $30 \mathrm{e}^{-4}$ & 182 \\
\hline & $\mathrm{L}$ & $\mathrm{L}$ & $\mathrm{R}$ & $\mathrm{L}$ & $\mathrm{R}$ & & & + & $30 \mathrm{f}$ & 182 \\
\hline I. trentonensis (Bassler, 1936) & $\mathrm{L}$ & $\mathrm{L}$ & $\mathrm{R}$ & $\mathrm{L}$ & $\mathrm{R}$ & & & + & 33 & 191 \\
\hline I. pleiadae (Sinclair and Bolton, 1965) & $\mathrm{L}$ & $\mathrm{L}$ & $?$ & $\mathrm{~L}$ & $\mathrm{R}$ & & & + & 34 & 193 \\
\hline \multirow{2}{*}{ Hemicystites parasiticus Hall, 1852} & $\mathrm{R}$ & $\mathrm{L}$ & $\mathrm{R}$ & $\mathrm{L}$ & $\mathrm{R}$ & & & + & $35 \mathrm{a}$ & 197 \\
\hline & $\mathrm{R}$ & $\mathrm{L}$ & $?$ & $\mathrm{~L}$ & $\mathrm{R}$ & & & + & $35 \mathrm{~b}$ & 197 \\
\hline Curvitriordo kentuckyensis (Bassler, 1936) & $\mathrm{L}$ & $\mathrm{L}$ & $\mathrm{R}$ ? & L? & $\mathrm{R}$ & & & + & 38 & 205 \\
\hline \multirow{2}{*}{ Agelacrinites hamiltonensis Vanuxem, 1842} & $\mathrm{R}$ & $\mathrm{L}$ & $\mathrm{R}$ & $\mathrm{L}$ & $\mathrm{R}$ & & & + & $40 \mathrm{~b}$ & 213 \\
\hline & $\mathrm{R}$ & $\mathrm{L}$ & $?$ & $\mathrm{~L}$ & $\mathrm{R}$ & & & + & $41 \mathrm{~d}$ & 215 \\
\hline \multirow[t]{4}{*}{ Krama devonicum (Bassler, 1936) } & $\mathrm{R}$ & $\mathrm{L}$ & $\mathrm{R}$ & $\mathrm{L}$ & $\mathrm{R}$ & & & + & 42 & 221 \\
\hline & $\mathrm{R}$ & & & & & & & + & $44 \mathrm{c}$ & 225 \\
\hline & $\mathrm{R}$ & & & & & & & + & $45 \mathrm{a}$ & 227 \\
\hline & $\mathrm{L}$ & & & & & & & + & $45 \mathrm{~b}$ & 227 \\
\hline
\end{tabular}

in opposite ways. In Foerstediscus grandis Bassler, 1935, pores code right in ambulacrum A, but cover plates code left. Finally, in two different species of Isorophus, ambulacrum A codes in opposite ways. Even if one ignores the cover plates, the pores of edrioasteroids code left more frequently than right in ambulacrum A (Table 1). It is difficult not to conclude that the motif in ambulacrum A was not fixed in edrioasteroids. In addition, some authorities (e.g., Mooi et al., 2005) argue that cover plates are not rigidly subject to the ocular plates rule of terminal addition and so should not be used in attempting to recognize Lovén's Law.

Diploporita.—Estonocystis Jaekel, 1918 (Fig. 9) is a diploporite that shows another type of BD different pattern of primary brachioles to that seen in glyptocystitoid Rhombifera. It differs from Lepadocystis in having only one oral in each ambulacrum, which does not contribute to a brachiole facet, and no L plate. Thereafter, brachiole facets arise from single plates, not pairs of flooring plates as in glyptoids. It is unique among diploporites with a regular ambulacral structure in having up to three facets per ambulacral plate on either side of the ambulacra. All other such diploporites have one facet per ambulacral flooring plate. Its 'BD different pattern' arises because the first ambulacral plate in ambulacra $\mathrm{B}$ and $\mathrm{D}$ has one more facet than the first ambulacral plate in ambulacra A, $\mathrm{C}$, and $\mathrm{E}$, typically three in $\mathrm{B}$ and $\mathrm{D}$, but only two in $\mathrm{A}, \mathrm{C}$, and E (Fig. 9.3).

Mature specimens do not show a Lovén-like pattern of ambulacral facets because the first two or three facets are on the first ambulacral plates, which lie on the left in all five ambulacra. The second pairs of facets are on the second ambulacral plates, which lie to the right in all ambulacra. Nevertheless, the simplest explanation of the extra facet in the first plate of ambulacra $\mathrm{B}$ and $\mathrm{D}$ is that they represent the $\mathrm{BC}^{1}$ combined and $\mathrm{DE}^{1}$ combined facets. If this is so, early in the development of the ambulacra when there were only ten facets, it is conceivable that both first facets in ambulacra B and D lay on the left within the first ambulacral plates, whereas in ambulacra A, C, 

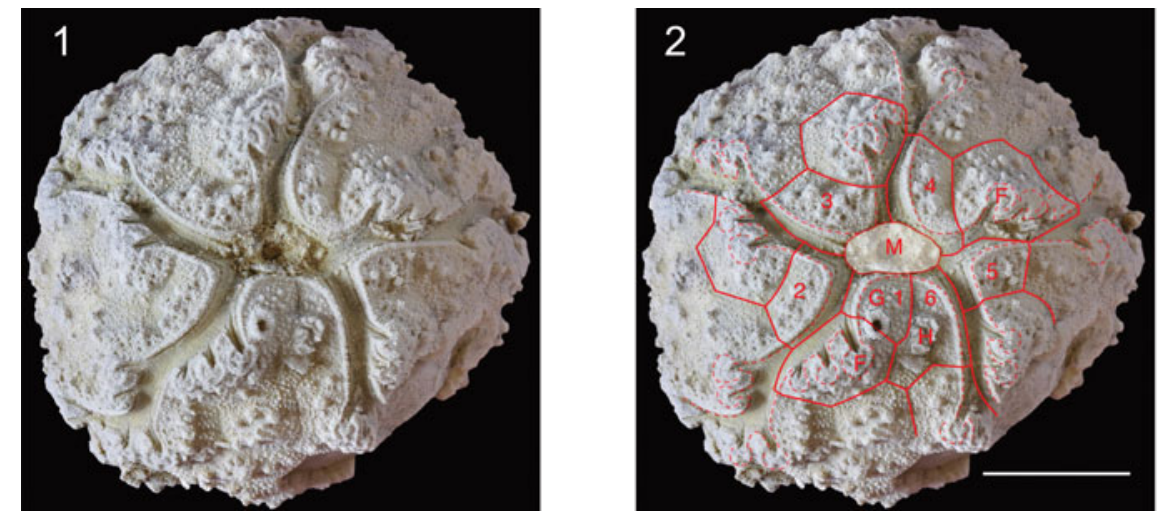

3

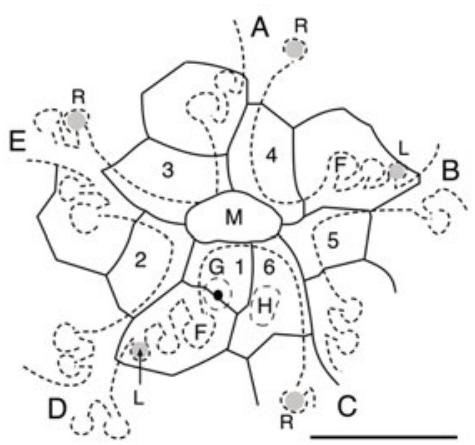

Figure 9. Estonocystis Jaekel, 1918. (1) Photo of TUG 1727-1, (2) photo plus plate outlines, (3) plate and ambulacral outlines with third brachiole facet in each ambulacrum shaded gray and labeled left $(\mathrm{L})$ or right $(\mathrm{R})$. Note third facets code A right, B left, C right, D left, E right, as in Lovén's Law. A-E = Carpenter's ambulacra; $\mathrm{F}=$ ambulacral facets $\mathrm{BC}^{1}$ and $\mathrm{DE}^{1} ; \mathrm{G}=$ gonopore; $\mathrm{H}=$ hydropore; $\mathrm{M}=$ mouth; $1-6=$ perioral plates. Solid lines = plate sutures, broken lines = outline of ambulacra and peristome. Scale bar $=5 \mathrm{~mm}$. Photo from Geoscience Collections of Estonia.

and $\mathrm{E}$, the first facet was on the left and the second on the right within the second ambulacral plate. This would have temporarily given a Lovén-like pattern of AR, BL, CR, DL, ER. Even so, the third brachiole facets in each ambulacrum of the specimen illustrated in Figure 9.3 code as AR, BL, CR, DL, ER: EA the unique pair of identical adjacent ambulacra.

The only other example from diploporite blastozoans is more convincing, but almost equally distinctive. Sphaeronitid diploporites entirely lack a regular ambulacral structure. The food grooves lack flooring and cover plates, but may extend over the theca and branch repeatedly. Sphaeronitids are united, among other things, by these food grooves plus a mouth frame composed of five radially positioned 'oral' plates, with a sixth in the CD inter-radius. The mouth is covered by six immovable, primary cover plates. Food entered the corners of the peristome through small ambulacral orifices, one per ambulacrum, and all branching of the food grooves occurs outside the limits of the

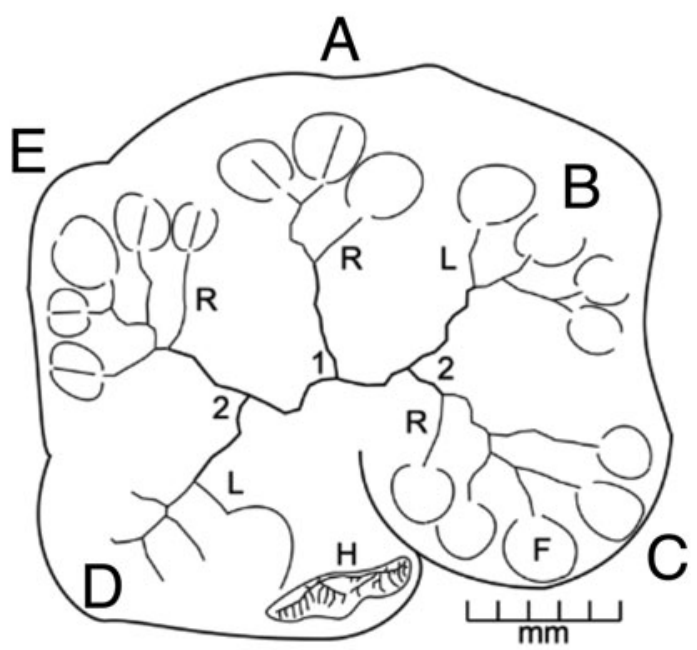

Figure 10. Camera lucida drawing from a latex cast of Batalleria? sp. to show 2-1-2 pattern of ambulacra (A-E) with first lateral branches to ambulacral facets (F) that fit Lovén's Law; A right, B left, C right, D left, E right; H = hydropore. peristome. Batalleria Chauvel and Meléndez, 1978 (Fig. 10) is related to sphaeronitids in having a similar mouth frame, but unique in having ambulacral branching within the peristome. The pattern of sutures between the oral cover plates shows the classic 2-1-2 branching (Fig. 10). In addition, the food grooves branch with the first lateral branch on the right in ambulacrum A, left in ambulacrum B, etc. in a classic Lovénian pattern (Fig. 10). Each food groove then leaves the mouth at a separate ambulacral orifice opposite a brachiole (?) facet, so that although no ambulacral plates are involved, clearly the soft-tissue structures, such as the radial water vessels, were branched.

\section{Interpretation}

To restate Lovén's Law in terms of the positions of first basicoronal ambulacral plates, using Lovén's ambulacral designations and Left and Right notation gives the following pattern:

IR, IIR, IIIL, IVR, VL (i.e., 3R, 2L with radii I and II the unique identical adjacent pair)

The transition from a triradiate 1-1-1 ambulacral pattern to a pentaradiate 2-1-2 pattern using Carpenter's ambulacral designations gives:

AR, BL, CR, DL, ER (i.e., 3R, 2L with radii $\mathrm{E}$ and $\mathrm{A}$ the unique pair)

Parsimony then suggests that Lovén's interradius I-II is homologous with Carpenter's EA, so we can derive the following ambulacral homologies:

$$
\begin{array}{llllll}
\text { IR } & \text { IIR } & \text { IIIL } & \text { IVR } & \text { VL } & \text { Lovén } \\
\text { ER } & \text { AR } & \text { BL } & \text { CR } & \text { DL } & \text { Carpenter }
\end{array}
$$

This is our fundamental hypothesis. Unfortunately, to be able to falsify this hypothesis requires a reliable independent landmark that can be recognized in all the classes of echinoderms that display Lovén-like ambulacral patterns. Currently, no such universal landmark can be recognized (see Testing homologies section above). Nevertheless, parsimony implies other important hypotheses. For example, our assumption of the homologies of Lovén's and Carpenter's radii is the simplest 
assumption only if Lovén's Law arose just once in the evolutionary history of the echinoderms. Secondly, if Lovén's Law is a consequence of the development of five ambulacra (as we argue above), it must have arisen early in the history of the echinoderms, and it should be widespread within the phylum. Finally, a plausible mechanism to explain how Lovén's Law arose is required to account for its fundamental nature. These are testable hypotheses and by making the first assumption we can investigate them.

A final point concerns the mechanism by which Lovén's Law can be recognized, especially in fossils. This includes the assumption that the order of ambulacral plates or lateral branches does not change during ontogeny. As originally stated, (Lovén, 1874) Lovén's Law was recognized using basicoronal ambulacral plates, which bear pores for the tube-feet/ampullae. Thus, both ambulacral plates and lateral branches of the radial water vessel (RWV) were involved. In other groups, we have used ambulacral flooring and cover plates (skeletal elements) as well as brachioles and ambulacral pores (lateral branches of the RWV). Strictly speaking, we need to know the homologies between echinoid ambulacral plates and fossil ambulacral plates. Here we argue that ambulacral flooring plates of blastozoan fossil echinoderms are homologous with echinoid ambulacral plates. Use of cover plates, in turn, requires knowledge of the relationship between cover plates and flooring plates. Ideally the two plate types should be in a 1:1 ratio or at least a known ratio and a fixed relationship, in order for cover plates to reveal Lovén's Law.

Origin of Lovén's Law.-A plausible mechanism for the original development of a Lovén-like pattern of primary ambulacral plates arises from the transition from a triradiate 1-1-1 ambulacral pattern to a pentaradiate 2-1-2 pattern. Walcottidiscus shows that as the paired lateral ambulacra bifurcate, new ambulacral flooring plates can only be inserted in the acute angles between the dividing ambulacra (Fig. 4). This inevitably causes the reversed motifs seen in Carpenter's ambulacra B-E. In ambulacrum B, for example, the left plate was already present when the right plate started to develop, whereas in ambulacrum $\mathrm{C}$ the right plate was already present. Extending the argument to ambulacra $\mathrm{D}$ and $\mathrm{E}$ gives an inevitable pattern of $\mathrm{BL}, \mathrm{CR}$, DL, ER. No other outcome is possible. Two Lovén-like patterns then become theoretically possible, with ambulacrum A Left or A Right. In Walcottidiscus, the first flooring plate in ambulacrum $\mathrm{A}$ is on the right, as it is in all echinoids under Lovén's Law as originally stated by Lovén. In edrioasteroids, both patterns occur and the ' $3 \mathrm{~L}, 2 \mathrm{R}$ with radii $\mathrm{A}$ and $\mathrm{B}$ the unique pair' pattern is more common (Table 1) than the strict interpretation of Lovén's Law (3R, 2L, A and $\mathrm{E}$ the unique pair). Nevertheless, at the very least, Lovén-like patterns of ambulacral flooring plates are an inevitable consequence of the development of five ambulacra from a triradial precursor in echinoderms.

Timing of origin.-Walcottidiscus was originally described from the Burgess Shale (Bassler, 1935, p. 3); Cambrian (Series 3, Stage 5). If Kailidiscus (Zhao et al., 2010) is a junior synonym (Sumrall and Zamora, 2015, p. 366), Walcottidiscus comes from a similar stratigraphic level in China. Regrettably, the specimen of
Walcottidiscus showing the oral plating is without locality information. Helicocystis, which Smith and Zamora considered to be the most primitive pentaradiate echinoderm, is known from Cambrian stage 4-5 boundary into the base of stage 5 (=Wuliuan Stage) (Smith and Zamora, 2013, p. 2). Other early pentaradiate echinoderms, such as Camptostroma Ruedemann, 1933, Stromatocystites (see Zamora et al., 2015), Kinzercystis Sprinkle, 1973, and Lepidocystis Foerste, 1938, also occur in Cambrian Series 2, Stage 4. Thus, the earliest known occurrence of Lovén-like patterns is contemporary with the appearance of five ambulacra in echinoderms, as revealed both by the fossil record and by cladistic analysis of early echinoderms.

Occurrence of Lovén's Law.-Lovén's Law was originally recognized in post-Paleozoic echinoids, which are eleutherozoans. Subsequently, Jackson (1912, 1927, 1929), Mortensen (1930), and Durham (1966a, figs. 214-217) recognized Lovén's Law in the Ordovician echinoid Bothriocidaris Eichwald, 1860. Among other Eleutherozoa, Lovén's Law has since been detected in Paleozoic lysophiurine ophiuroids (Hotchkiss, 1978, 1995; Harper, 1985), ophiocistioids, and the specialized edrioasteroid Astrocystites (Hotchkiss, 1995), as well as the already discussed lower Cambrian edrioasteroid, Walcottidiscus (= Stromatocystites in David et al., 1995; Hotchkiss, 1995). In addition, it has been detected in metamorphosing holothurians (Smirnov, 2014) and the pharyngial ring of a Devonian holothurian (Haude, 1994). Herein, we recognize the basic pattern in the Paleozoic pelmatozoan groups Rhombifera and Diploporita. Furthermore, Lovén-like patterns are common among the ambulacral cover plates of edrioasteroids (Bell, 1976; Table 1, herein). Thus, again, it would seem that even restricting our observations to the original pattern identified by Lovén (1874), Lovén's Law is widespread among both eleutherozoan and pelmatozoan echinoderms. The more so because Lovén's Law cannot be detected in a number of echinoderm taxa, either because they are characterized by fewer than five ambulacra (e.g., hemicosmitoid and caryocystitoid rhombiferans, flattened eocrinoids), or because their ambulacra are uniserial (e.g., most crinoids and paracrinoids). The facts above are consistent with the idea that Lovén's Law arose only once and early in the evolution of the echinoderms. Indeed, it appears to have been an integral part of the process of deriving pentaradiate echinoderms from triradiate ancestors. Independently, Smith (1997, p. 236) concluded that Lovén's Law was "too unusual to have arisen multiply by chance."

\section{Discussion}

Lovén's Law was originally proposed using echinoid basicoronal ambulacral plates, which we think are homologous with at least some pelmatozoan ambulacral flooring plates. Here we have recognized similar or identical patterns using both ambulacral flooring and cover plates. In some cases (e.g., edrioasterid edrioasteroids), the cover plates not only match the flooring plates in a 1:1 ratio, but are aligned exactly with the flooring plates (see, for example, Bell, 1976, p. 27). Thus, in this case, use of cover plates is justified. In isorophid edrioasteroids, the 
situation is more complex. Many develop complex cover plate series, making recognition of the first ambulacral cover plates more difficult. In the $\mathrm{C}$ ambulacrum, the presence of hydropore cover plates makes it more difficult to recognize on which side of the ambulacrum the first cover plate lies. Furthermore, there is evidence that additional cover plates may have developed over the mouth after the first ambulacral cover plates formed. Most isorophid edrioasteroids have uniserial ambulacral flooring plates, which cannot therefore demonstrate a Lovénian pattern. Thus, it is possible to argue that isorophid edrioasteroids cannot be used to recognize Lovén's Law. On the other hand, it is bad practice to dismiss out of hand anomalous examples that do not fit the current hypothesis. They may be the critical evidence that invalidates the hypothesis. So, it is particularly regrettable that many isorophid edrioasteroids present a Lovén-like pattern of first ambulacral cover plates that is $\mathrm{AL}, \mathrm{BL}, \mathrm{CR}, \mathrm{DL}, \mathrm{ER} ; 3 \mathrm{~L}$, $2 \mathrm{R}, \mathrm{AB}$ the unique pair of identical adjacent ambulacra. Here we simply present this difficulty, but think it would be a good idea to investigate first ambulacral plate patterns in edrioasteroids as a separate study, especially because neither of us is an expert on edrioasteroid morphology. In addition, Sumrall and Zamora (2011) have shown that the so-called 'hood plates' of pyrgocystid edrioasteroids are homologues of the outer flooring plates of Kailidiscus, so it is possible that Lovén's Law might be recognizable in pyrgocystids.

Our general thesis is that Lovén's Law came about in the transition from a triradiate 1-1-1 ambulacral pattern to the pentaradiate 2-1-2 pattern observed in many early echinoderms from the lower Cambrian onwards. Therefore, one might expect Lovén's Law to be obviously present in all pentaradiate echinoderms with biserial, alternate ambulacra. We can detect Lovén's Law widely in glyptocystitoid rhombiferans, for example Coronocystis, Lepadocystis, and Callocystites (Figs. 5-7), but rarely if ever in other rhombiferans. This is partly because hemicosmitoid rhombiferans are fundamentally triradiate (Bockelie, 1979; Sumrall, 2008) and Lovén's Law can only be recognized in pentaradiate echinoderms. Even the sole exception among hemicosmitoids, Thomacystis Paul, 1969, has four ambulacra. Similarly, caryocystitoid rhombiferans have only two to four ambulacra (Bockelie, 1981a, b, 1982a, b). Thus, Lovén's Law cannot be recognized in two of the three major groups of rhombiferans. On the other hand, a majority of diploporites are pentaradiate (Bockelie, 1984), and yet we can only point to two genera that show a Lovén-like pattern, and one of those is doubtful. However, some diploporites with a definite ambulacral structure have uniserial ambulacra. Those without regular ambulacra entirely lack flooring or cover plates. In both cases, Lovén's Law cannot be detected, nor can it be detected in the majority of crinoids because of their uniserial ambulacra. Here again, however, the situation is more complicated. Some early crinoids do have biserial flooring plates (Guensburg et al., 2020), and we have detected one possible case of Lovén's Law in Hybocrinus nitidus Sinclair, 1945 (see Guensburg et al., 2016, fig. 2F). Again, a systematic search among suitable crinoid genera might be fruitful.

If, as we maintain here, Lovén's Law is a fundamental feature of echinoderm morphology that was initially developed as a result of the transition from the triradiate 1-1-1 to a pentaradiate 2-1-2 ambulacral pattern, then the distinction between 'true pentamery' (Sumrall and Wray, 2007), as seen in echinoids, for example, and 'pseudo-pentamery' as seen in glyptocystitoid rhombiferans and other early pentaradiate echinoderms, is a false distinction.

\section{Conclusions}

Lovén's Law is best stated using the position (Left or Right) of the first basicoronal ambulacral plates or lateral branches of ambulacral soft-tissue structures, such as the water vascular system, and so becomes IR, IIR, IIIL, IVR, VL; I and II unique identical adjacent ambulacra, using Lovén's system of denoting ambulacra. The transition from a triradiate 1-1-1 to a pentaradiate 2-1-2 ambulacral arrangement, as seen in the lower Cambrian edrioasteroid Walcottidiscus, produced a pattern of first ambulacral plates that is AR, BL, CR, DL, ER; E and A the unique pair of ambulacra, using Carpenter's system of denoting ambulacra. The pattern for ambulacra B-E is inevitable. Subterminal branching of ambulacral soft-tissue structures in pentaradiate glyptocystitoid rhombiferans predicts the development of the 'BD different pattern' of primary brachioles, in which the first two brachioles branch to the left in ambulacra $B$ and D, but only the first one in ambulacra A, C, and E. Second brachioles in pentaradiate glyptocystitoid rhombiferans branch AR, BL, CR, DL, ER; E and A the unique pair of ambulacra. This classic Lovénian pattern only results if the order of branching was: develop three ambulacra with one brachiole, bifurcate the lateral pair to give five ambulacra with one brachiole, develop second brachioles in all five ambulacra. Other classes of fossil echinoderms also produce examples of Lovén's Law.

Based on simultaneous expression of Lovén's Law (morphology) and 2-1-2 symmetry (morphology) in the edrioasteroids Astrocystites Whiteaves and Walcottidiiscus Bassler (= Stromatocystites of Hotchkiss, 1995, figs. 3, 4), we deduce reciprocal homology between rays expressed in the Carpenter system and rays expressed in the Lovenian system. In this specimen-based comparison, we observe that Carpenter letters A, B, C, D, E (labels) are arranged in relation to 2-1-2 symmetry (morphology) as DE-A-BC (pattern), and that Lovén's numerals I, II, III, IV, V (labels) are arranged in relation to 2-1-2 symmetry (morphology) as V,I - II - III,IV (pattern). This is our working hypothesis and method concerning ray homologies.

Thus, IR, IIR, IIIL, IVR, VL; I and II the unique pair, is homologous with ER, AR, BL, CR, DL; E and A the unique pair, and controls the homology of ambulacra in all pentaradiate echinoderms. Testing this hypothesis requires a reliable independent landmark across all classes of pentaradiate echinoderms, which has not yet been discovered. We recommend seeking such a landmark in the ontogeny of the living classes. Closure of the ring canal seems a distinct possibility (Sedgwick, 1909, p. 119; de Lussanet, 2011, fig. 2). Nevertheless, parsimony predicts that Lovén's Law arose only once, early in echinoderm evolution, and that it should be widespread within the phylum. Both conditions appear to be met, and we also have a plausible mechanism by which Lovén's Law arose coincident with the development of five ambulacra. Isorophid edrioasteroids produce a pattern AL, BL, CR, DL, ER; A and B the unique pair of identical adjacent ambulacra in their ambulacral cover plates more often than the true Lovén's Law. 
Of the original hypotheses mentioned in the introduction, the second, that Lovén's Law is confined to echinoids, can be rejected because examples can be recognized in other classes. We also reject the third, that different Lovén-like patterns occur in different classes, and conclude that Lovén's Law can be recognized in its original form in other classes of Paleozoic echinoderms.

\section{Acknowledgments}

The photograph of Estonocystis in Figure 9 was downloaded from the Geoscience collections of Estonia website; @ Baranov. CRCP had useful discussions with E. Nardin concerning the 'BD different' ambulacral pattern and help with the figures from J. Marriage. FHCH thanks G. Wray, S. Donovan, R. Mooi, D. Blake, and I. Rahman for years of discussions; and M. Clain, D. Clain, A.H. Ganz, R.N. Ganz, and W.K. and E.G. Hoskins, for sustaining support. R. Mooi, A. Smith, J. Thompson, and S. Zamora provided extremely helpful reviews of various drafts of the manuscript. We thank W.K. and E.G. Hoskins for a grant to MPRI to make this an open access paper. This is MPRI Contribution number 9 .

\section{References}

Bassler, R.S., 1935, The classification of the Edrioasteroidea: Smithsonian Miscellaneous Collections, v. 93, pt. 8, p. 1-11.

Bassler, R.S., 1936, New species of American Edrioasteroidea: Smithsonian Miscellaneous Collections, v. 95, pt. 6, p. 1-33.

Bather, F.A., 1900, The Echinoderma, in Lankester, E.R., ed., A Treatise on Zoology, Pt. 3: London, A \& C Black, 344 p.

Bather, F.A., 1914, The edrioasters of the Trenton Limestone, pts. 1 and 2: Geological Magazine (n.s.) decade 6, v. 1, p. 115-125; 162-171.

Bell, B.M., 1976, A study of North American Edrioasteroidea: New York State Museum, Memoir 21, p. 1-447.

Billings, E., 1857, Report for the year 1856, Fossils from Anticosti, and new species of fossils from the Lower Silurian rocks of Canada: Geological Survey of Canada, Report of Progress, 1853-1856, p. 247-345.

Bockelie, J.F., 1979, Taxonomy, functional morphology and palaeoecology of the Ordovician cystoid family Hemicosmitidae: Palaeontology, v. 22, p. 363-406.

Bockelie, J.F., 1981a, A re-evaluation of the Ordovician cystoid Stichocystis Jaekel and the taxonomic implications: Geologiska Föreningens i Stockholm Förhandlingar, v. 103, p. 51-59.

Bockelie, J.F., 1981b, Functional morphology and evolution of the cystoid Echinosphaerites: Lethaia, v. 14, p. 189-202.

Bockelie, J.F., 1982a, Symmetry and ambulacral pattern of the rhombiferan superfamily Caryocystitida and their relationship to other Blastozoa: Geologiska Föreningens i Stockholm Förhandlingar, v. 103, p. 491-498.

Bockelie, J.F., 1982b, Morphology, growth and taxonomy of the Ordovician rhombiferan Caryocystites: Geologiska Föreningens i Stockholm Förhandlingar, v. 103, p. 499-513.

Bockelie, J.F., 1984, The Diploporita of the Oslo region, Norway: Palaeontology, v. 27 , p. $1-68$.

Breimer, A., 1978, General Morphology. Recent crinoids, in Moore, R.C., and Teichert, C., eds., Treatise on Invertebrate Paleontology, Pt. T, Echinodermata 2: Boulder, Colorado and Lawrence, Kansas, Geological Society of America and University of Kansas Press, p. T9-T58.

Callaway, C., 1877, On a new area of Upper Cambrian rocks in south Shropshire, with a description of a new fauna: Quarterly Journal of the Geological Society, London, v. 33, p. 652-672.

Carpenter, P.H., 1884, Report upon the Crinoidea collected during the voyage of HMS Challenger during the years 1873-76, pt. 1. General morphology with descriptions of the stalked crinoids: Reports of the Scientific Results of the Voyage of HMS Challenger: Zoology, v. 11, p. 1-442.

Carpenter, P.H., 1891, On certain points of the morphology of the Cystidea: Journal of the Linnean Society (Zoology), v. 24, p. 1-52.

Chauvel, J., and Meléndez, B., 1978, Les Echinodermes (Cystoïdes, Astérozoaires, Homalozoaires) de l'Ordovicien moyen des Monts de Tolède: Estudios Geológicos, v. 34, p. 75-87.
David, B., Mooi, R., and Telford, M., 1995, The ontogenetic basis of Lovén's Rule clarifies homologies of the echinoid peristome, in Emson, R.H., Smith, A.B., and Campbell, A., eds., Echinoderm Research: Rotterdam, Balkema, p. 155-164.

de Lussanet, M.H.E., 2011, A hexamer origin of the echinoderms' five rays: Evolution and Development, v. 13, p. 228-238.

Durham, J.W., 1966a, Classification [of echinozoans], in Moore, R C., ed., Treatise on Invertebrate Paleontology, Pt. U, Echinodermata 3: Boulder, Colorado and Lawrence, Kansas, Geological Society of America and University of Kansas, p. U270-U297.

Durham, J.W., 1966b, Evolution among the Echinoidea: Biological Reviews, v. 41 , p. $368-391$

Eichwald, E. von, 1860, Lethaea Rossica: Stuttgart, Schweizerbart, vol. 1, 1,657 p.

Fell, H.B., 1966, Ancient echinoderms in modern seas: Oceanography and Marine Biology Annual Reviews, v. 4, p. 233-245.

Fell, H.B., and Pawson, D.L., 1966, General biology of echinoderms, in Boolootian, R.A., ed., Physiology of Echinodermata: Interscience: New York, John Wiley \& Sons, p. 1-48.

Foerste, A.F., 1914, Notes on Agelacrinidae and Lepadocystinae, with descriptions of Thresherodiscus and Brockocystis: Denison University Science Laboratories Bulletin, v. 17, p. 399-487.

Foerste, A.F., 1938., Echinodermata, in Resser, C.E., and Howell, B.F., eds., Lower Cambrian Olenellus Zone of the Appalachians: Geological Society of America, Bulletin, v. 49, p. 212-213.

Guensburg, T.E., Blake, D.B., Sprinkle, J., and Mooi, R., 2016, Crinoid ancestry without blastozoans. Acta Palaeontologica Polonica, v. 61, p. 253-266. https://doi.org/10.4202/app.00211.2015.

Guensburg, T.E., Sprinkle, J., Mooi, R., Lefebvre, B., David, B., Roux, M., and Derstler, K., 2020, Athenacrinus, n. gen. and other early echinoderm taxa inform crinoid origins and arm evolution. Journal of Paleontology, v. 94, p. 311-333. doi: 10.1017/jpa.2019.87.

Hall, J., 1852, Paleontology of New York, Volume 2, Containing Descriptions of the organic remains of the Lower Middle Division of the New York System. Natural History of New York, Pt. 6: Albany, D. Appleton and Wiley and Putnam, $362 \mathrm{p}$

Hall. J., 1866, Descriptions of some new species of Crinoidea and other fossils: New York State Museum, Annual Report, v. 20 (advanced publication), p. $1-17$.

Hall. J., 1871, Descriptions of some new species of fossils, from the shales of the Hudson River Group, in the vicinity of Cincinnati: New York State Museum, Annual Report, v. 24 (advanced publication), p. 1-8.

Harker, P., 1953, A new edrioasteroid from the Carboniferous of Alberta: Journal of Paleontology, v. 27, p. 288-289.

Harper, J.A., 1985, A new look at Eugasterella logani (Hall, 1868) (Stelleroidea: Ophiuroidea) from the Middle Devonian of New York State: Carnegie Museum, Annals, v. 54, p. 357-373.

Haude, R., 1994, Fossil holothurians: constructional morphology of the sea cucumber, and the origin of the calcareous ring, in David, B., Guile, A., Feral, J.P., and Roux, M., eds., Echinoderms Through Time: Proceedings of the Eighth International Echinoderm Conference, Dijon, 6-10 Sept. 1993: Rotterdam, Balkema, p. 517-522.

Hotchkiss, F.H.C., 1978, Studies on echinoderm ray homologies: Lovén's Law applies to Paleozoic ophiuroids: Journal of Paleontology, v. 52, p. 537-544.

Hotchkiss, F.H.C., 1995, Lovén's Law and adult ray homologies in echinoids, ophiuroids, edrioasteroids and an ophiocistioid: Biological Society of Washington, Proceedings, v. 108, p. 401-435.

Hotchkiss, F.H.C., 1998a, A "rays-as-appendages" model for the origin of pentamery in echinoderms: Paleobiology, v. 24, p. 200-214.

Hotchkiss, F.H.C., 1998b, Discussion on pentamerism: the five-part pattern of Stromatocystites, Asterozoa and Echinozoa, in Mooi, R., and Telford, M., eds., Echinoderms, San Francisco: Rotterdam, Balkema, p. 37-42.

Hotchkiss, F.H.C., 2000, On the number of rays in starfish: American Zoologist, v. 40 , p. $340-354$

Hyman, L.H., 1955, The Invertebrates: Echinodermata: New York, McGraw Hill Book Co., 763 p.

Jackson, R.T., 1912, Phylogeny of the Echini, with a revision of Palaeozoic species: Boston Society of Natural History, Memoirs, v. 7, p. 1-491.

Jackson, R.T., 1927, Studies of Arbacia punctulata and allies, and of nonpentamerous Echini: Boston Society of Natural History, Memoirs, v. 8, p. 437-565.

Jackson, R.T., 1929, The status of Bothriocidaris: Museum of Comparative Zoology at Harvard College, Bulletin, v. 69, p. 481-512.

Jaekel, O., 1899, Stammesgeschichte der Pelmatozoen. 1. Thecoidea und Cystoidea: Berlin, Julius Springer, $442 \mathrm{p}$.

Jaekel, O., 1918, Phylogenie und System der Pelmatozoen: Paläontologisches Zeitschrift, v. 3, p. 1-128.

Jefferys, W.H., and Berger, J.O., 1992, Ockham's razor and Bayesian analysis: American Scientist, v. 80, p. 64-72.

Kier, P.M., 1968, Echinoids from the Middle Eocene Lake City Formation of Georgia: Smithsonian Miscellaneous Collections, v. 153, pt. 2, p. 1-45. 
Lovén, S., 1874, Études sur les echinoidées: Kongelige Svenska Vetenskapsakademie Handlingar (new series), v. 11, p. 1-91.

Meek, F.B., 1871, On some new Silurian crinoids and shells: American Journal of Science, Series 3, v. 2, p. 295-299.

Meek, F.B., and Worthen, A.H., 1868, Remarks on some types of Carboniferous Crinoidea, with descriptions of new genera and species of the same, and one echinoid: Academy of Natural Sciences of Philadelphia, Proceedings, v. 5, p. 335-359.

Miller, S.A., and Gurley, W.F.E., 1894, New genera and species of Echinodermata: Illinois State Museum Bulletin, v. 5, p. 5-53.

Mooi, R., and David, B., 1997, Skeletal homologies of echinoderms, in Waters, J.A., and Maples, C.G., eds., Geobiology of Echinoderms: Paleontological Society Papers, v. 3, p. 305-335.

Mooi, R., David, B., and Wray, G.A., 2005, Arrays in rays: terminal addition in echinoderms and its correlation with gene expression: Evolution and Development, v. 7, p. 542-555.

Mortensen, T., 1930, Bothriocidaris and the ancestry of echinoids. A reply: Videnskabelige Meddelelser fra Dansk naturhistorisk forening København, v. 90, p. 313-352.

Paul, C.R.C., 1968, Macrocystella Callaway, the earliest glyptocystitid cystoid: Palaeontology, v. 11, p. 580-600.

Paul, C.R.C., 1969, Thomacystis, a unique new hemicosmitid cystoid from Wales: Geological Magazine, v. 106, p. 190-196.

Paul, C.R.C., 1972, Cheirocystella antiqua gen. et sp. nov. from the Lower Ordovician of western Utah, and its bearing on the evolution of the Cheirocrinidae (Rhombifera: Glyptocystitida): Brigham Young University Geology Studies, v. 19, p. 15-63.

Paul, C.R.C., 2015a, Callocystites fresti sp. nov., and the significance of ambulacral branching in the Callocystitidae (Echinodermata, Glyptocystitoida) Geological Journal, v. 50, p. 189-209. doi: 10:1002/gj.2545.

Paul, C.R.C., 2015b, A cystoid with two left facets: the significance of Tetracystis in the evolution and classification of the Callocystitidae (Echinodermata Glyptocystitoida): Geological Journal, v. 50, p. 607-633. doi: 10:1002/ gj.2578.

Paul, C.R.C., 2017, Testing for homologies in the axial skeleton of primitive echinoderms: Journal of Paleontology, v. 91, p. 582-603.

Paul, C.R.C., and Donovan, S.K., 2011, A review of the British Silurian cystoids: Geological Journal, v. 46, p. 434-450.

Paul, C.R.C., and Smith, A.B., 1984, The early radiation and phylogeny of the echinoderms: Biological Reviews, v. 59, p. 443-481.

Raymond, 1915, Revision of Canadian species of Agelacrinites: Ottawa Naturalist, v. 29 , p. 53-62.

Roemer, C.F. von, 1851, Beiträge zur Kenntnis der fossilien Fauna des devonischen Gebirges am Rhein: Decheniana, v. 8, p. 357-376.

Rozhnov, S.V., 2014, Symmetry of echinoderms: from initial bilaterally-asymmetric metamerism to pentaradiality: Natural Science, v. 6 , p. $171-183$.

Ruedemann, R., 1933, Camptostroma, a Lower Cambrian floating hydrozoan: US National Museum, Proceedings, v. 82 , article 13, p. 1-8.

Saucède, T., Mooi, R., and David, B., 2003, Combining embryology and paleontology: origins of the anterior-posterior axis in echinoids: Comptes Rendus Palevol, vol. 2, p. 399-412.

Saucède, T., Mooi, R., and David, B., 2007, Phylogeny and origin of Jurassic irregular echinoids (Echinodermata: Echinoidea): Geological Magazine, v. 144, p. 333-359.

Sedgwick, A., 1909, A Student's Textbook of Zoology: Volume 3, Chapter III Phylum Echinodermata: London, Swan Sonnenschein and Co. Ltd, p. 115313.

Sinclair, G.W., 1945, Some Ordovician echinoderms from Oklahoma: American Midland Naturalist, v. 34, p. 707-716.

Sinclair, G.W., and Bolton, T.E., 1965, A new species of Hemicystites: Geological Survey of Canada Bulletin, v. 134, p. 35-39.
Smirnov, A.V., 2014, Sea cucumbers symmetry (Echinodermata: Holothuroidea): Paleontological Journal, v. 48, p. 1215-1236.

Smith, A.B., 1997, Echinoderm larvae and phylogeny: Annual Review of Ecology and Systematics, v. 28, p. 219-241.

Smith, A.B., and Zamora, S., 2013, Cambrian spiral-plated echinoderms from Gondwana reveal the earliest pentaradial body plan: Royal Society, London, Proceedings, B Biological Sciences, v. 280, 20131197. doi 10.1098/ rspb.2013.1197.

Sprinkle, J., 1973, Morphology and evolution of blastozoan echinoderms: Museum of Comparative Zoology, Harvard University, Special Publication, $284 \mathrm{p}$.

Sumrall, C.D., 2005, The origin of Lovén's Law in glyptocystitoid rhombiferans and its bearing on the hemicosmitoid peristomial border: Geological Society of America Abstracts with programs, v. 37, pt. 7, p. 63 .

Sumrall, C.D. 2008, The origin of Lovén's law in glyptocystitoid rhombiferan and its bearing on the plate homology and heterochronic evolution of the hemicosmitoid peristomial border, in Ausich, W.I., and Webster, G.D. eds., Echinoderm Paleobiology: Bloomington, University of Indiana Press, p. 228-241.

Sumrall, C.D., 2010, A model for elemental homology for the peristome and ambulacra in blastozoan echinoderms, in Harris, L.G., Böttger, S.A., Walker, C.W., and Lesser, M.P., eds., Echinoderms: Durham: London, CRC Press, p. 269-276.

Sumrall, C.D., and Sprinkle, J., 1999, Early ontogeny of the glyptocystitid rhombiferan Lepadocystis moorei, in Carnevalli, M.D.C., and Bonasoro, F., eds., Echinoderm Research 1998. Proceedings of the Fifth European Conference on Echinoderms: Rotterdam, Balkema, p. 409-414.

Sumrall, C.D., and Waters, J., 2012, Universal elemental homology in glyptocystitoids, hemicosmitoids, coronoids and blastoids: steps towards echinoderm phylogenetic reconstruction in derived Blastozoa: Journal of Paleontology, v. 86, p. 956-972.

Sumrall, C.D., and Wray, G.A., 2007, Ontogeny in the fossil record: diversification of body plans and the evolution of "aberrant" symmetry in Paleozoic echinoderms: Paleobiology, v. 33, p. 149-163.

Sumrall, C.D., and Zamora, S., 2011, Ordovician edrioasteroids from Morocco: faunal exchanges across the Rheic Ocean: Journal of Systematic Palaeontology, v. 9, p. 425-454. doi: 10.1080/14772019.2010.499137.

Sumrall, C.D., and Zamora, S., 2015, A columnal-bearing eocrinoid from the Cambrian Burgess Shale (British Columbia, Canada): Journal of Paleontology, v. 89, p. 366-368. doi: 10.1017/jpa.2014.54

Tsuchimoto, J., Yamada, T., and Yamaguchi, M., 2011, Unusual coelom formation in the direct-type developing sand dollar Peronella japonica: Developmental Dynamics, v. 240, p. 2432-2439.

Vanuxem, L., 1842, Survey of the third geological district: Natural History of New York, Pt. 4, Geology, v. 3, p. 1-307.

Whiteaves, J.F., 1897, Description of a new genus and species of cystidean from the Trenton Limestone of Ottawa: Canadian Record of Science, v. 7, p. 287-292, 395-396.

Wood., E., 1909, A critical review of Troost's unpublished manuscript on the crinoids of Tennessee: United States National Museum, Bulletin, v. 64 (11), p. 1-150.

Zamora, S., Lefebvre, B., Hozgör. I., Franzen, C., Nardin, E., Fatka, O., and Álvaro, J.J., 2015, The Cambrian edrioasteroid Stromatocystites (Echinodermata): systematics, palaeogeography, and palaeoecology: Geobios, v. 48, p. $417-426$.

Zhao, Y., Sumrall, C.D., Parsley, R.L., and Peng, J. 2010. Kailidiscus, a new plesiomorphic edrioasteroid from the basal Middle Cambrian Kaili biota of Guizhou Province, China: Journal of Paleontology, v. 84, p. 668-680.

Accepted: 23 April 2020 